\author{
Universidade de São Paulo \\ Instituto de Psicologia \\ Curso de Pós-Graduação em Psicologia
}

\title{
A FELICIDADE REVISITADA: UM ESTUDO SOBRE BEM-ESTAR-SUBJETIVO NA VISÃO DA PSICOLOGIA POSITIVA
}

Lilian D. Graziano

São Paulo

2005 
Universidade de São Paulo

Instituto de Psicologia

Curso de Pós-Graduação em Psicologia

\section{A FELICIDADE REVISITADA: UM ESTUDO SOBRE BEM-ESTAR-SUBJETIVO NA VISÃO DA PSICOLOGIA POSITIVA}

Tese apresentada ao Instituto de Psicologia da Universidade de São Paulo, como parte dos requisitos para a obtenção do grau de Doutora em Psicologia, área de concentração Psicologia Escolar e do Desenvolvimento Humano.

Candidata: Lilian D. Graziano

Orientadora: Profa. Dra . Maria Isabel da Silva Leme

Comissão Julgadora:

Profa. Dra . Maria Isabel da Silva Leme

Prof. Dr. Antonio da Costa Ciampa

Prof. Dr. Dirceu da Silva

Prof. Dr. Ives de La Taille

Prof. Dr. Ricardo Franklin Ferreira

São Paulo

2005 


\section{FICHA CATALOGRÁFICA}

\section{Graziano, L.}

A Felicidade Revisitada: Um estudo sobre o bem-estar-subjetivo na visão da Psicologia Positiva / Lilian Graziano. São Paulo. S.n., 2005.

Tese (doutorado) - Instituto de Psicologia da Universidade de São Paulo. Departamento de Psicologia da Aprendizagem e do Desenvolvimento Humano.

Orientadora: Prof ${ }^{a}$. Dr ${ }^{\text {a }}$. Maria Isabel da Silva Leme

1. Felicidade 2. Psicologia Positiva 3.Bem-estar-subjetivo

4. Locus de Controle 5.Flow I. Título 
Dedico este trabalho a todas as pessoas (psicólogos ou não) que acreditam na felicidade e, mais do que isso, sabem que "ser feliz dá trabalho". 


\section{AGRADECIMENTOS}

Quis a vida que aos 15 anos de idade eu visse o caminho que até então trilhara, abrir-se, abruptamente, numa encruzilhada onde apenas uma das vias seria capaz de conduzir-me à felicidade. Uma felicidade que, naquele momento, colocavase distante de mim como jamais estivera e cuja existência eu provara com uma brevidade cruel.

Por uma razão que até hoje desconheço, decidi-me pela trilha que me levaria àquele destino que meus olhos adolescentes viam como impossível. E então, 25 anos se passaram para que eu chegasse até ele, até uma vida que, de fato, considero feliz.

Durante essa longa jornada há tantas pessoas a agradecer, talvez mais ainda do que eu possa supor. Contudo, num autêntico exercício de Psicologia Positiva, volto minha gratidão àqueles que, certamente, fizeram parte dessa trajetória e que fortemente contribuem para minha felicidade:

Ao Fábio sou-lhe grata por sua existência, por estar sempre comigo, ter me ajudado a descobrir que esta "sempre fora minha linha de pesquisa" e, principalmente, por ter me feito voltar a acreditar no amor e, mais do que isso, num amor resistente ao tempo e capaz de se transformar conosco.

Aos filhos maravilhosos, fonte de extrema felicidade, que permitiram que eu me realizasse como mãe sem que, para isso, fosse preciso sacrificar a mulher: À querida Juliana que, ao me ver como sua melhor amiga, sempre acreditou ser apenas eu aquela que ensina, sem se dar conta de sua própria importância para que eu conseguisse resgatar meu lado feminino.

E ao meu filho Lucas, "amigo de longa data" que, ao optar (como eu) por não ser uma "pessoa normal", tem se mostrado um homem verdadeiro e muito melhor do que qualquer outro que já conheci. 
À Maria Lúcia Camões da Costa, amiga e terapeuta que, ao legitimar a pessoa que eu era, ensinou-me a ter orgulho da pessoa que sou.

Agradeço também por ter uma família cujas qualidades aprendi a admirar e cuja companhia adoro desfrutar em momentos autenticamente "italianos" onde todos se encontram reunidos: minha mãe, a Val, a "gatinha", a Adriana, o Ricardão e todos os "Grazianos" que me fazem sentir mais próxima da minha querida avó Maria Amélia.

E aos amigos que tornaram minha família ainda maior: Gildo, Cristina (Maria), Simone, Clark, Frank, Fabíola, Tatá, Waltinho e, é claro, a mais nova (e fofinha) integrante da turma: minha querida afilhada Bruninha, cujas bochechas rosadas são ícones da mais pura vida feliz.

Devo muito de minha felicidade ao fato de ter seguido a profissão que tanto amo e que, de uma forma ou de outra, permitiu-me também conhecer pessoas maravilhosas como a Cláudia, o Maurício, a Landa, o Carlinhos e tantas outras cujos nomes, embora não cite, permanecerão pra sempre em meu coração. Dentre eles, destaco ainda o de James Wygand, amigo e sócio a quem admiro profundamente pela competência, integridade e sensibilidade e também pela infinita paciência que demonstrou diante das ausências que me permitiram concluir esta tese.

Ao Prof. Dr. Adail Victorino Castilho agradeço por ter me acolhido nesta Instituição e à Profa. Dra. Maria Isabel da Silva Leme sou grata não apenas por ela ter me "adotado" como sua orientanda, mas, sobretudo, por ter me auxiliado a encontrar meu verdadeiro caminho.

Ao Prof. Dr. Ricardo Franklin Ferreira e Prof. Dr. Antonio da Costa Ciampa, agradeço pelas valiosas contribuições feitas por ocasião da qualificação.

À Fundação Álvares Penteado (FECAP) agradeço o indispensável apoio recebido através da pessoa do seu magnífico reitor, Prof. Manuel Nunes Pinto e sem o qual esta pesquisa se tornaria impossível. 
Agradeço também aos meus alunos queridos, pelos quais mantenho aceso meu desejo de transformar o mundo.

E, finalmente, devo ainda agradecer ao meu eternamente querido Júnior pelo início de tudo...

... e a mim mesma, por ter escolhido o caminho "impossível"... 
SUMÁRIO

Página

Índice de Tabelas ........................... 10

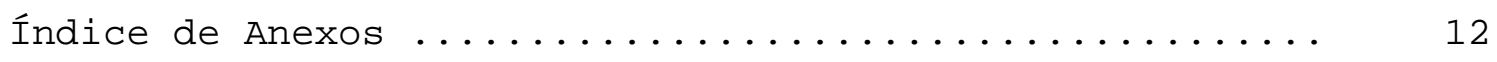

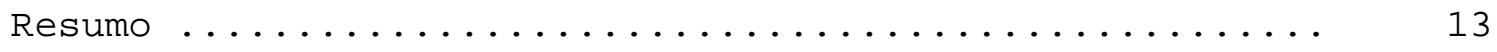

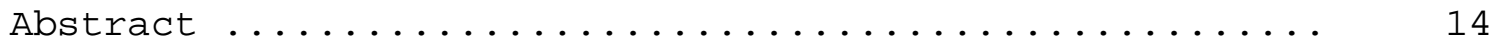

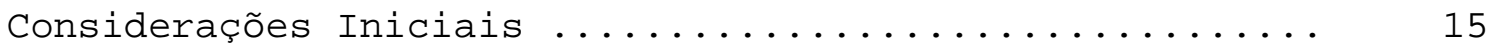

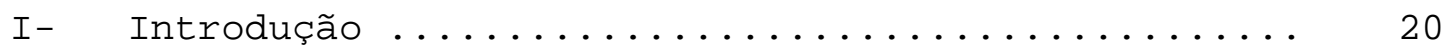

1.1. A Psicologia Positiva ................... 20

1.2. A Felicidade Humana .................... 35

1.2.1. Prazer e Gratificação na Psicologia Positiva. 46

1.2.2. O Conceito de Flow ................... 59

1.3. Virtude, Caráter e Forças Pessoais ............. 68

1.4. Locus de Controle ........................ 75

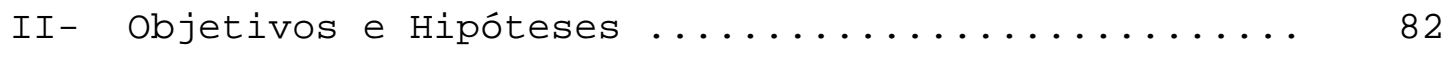

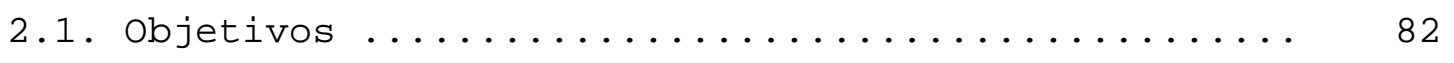

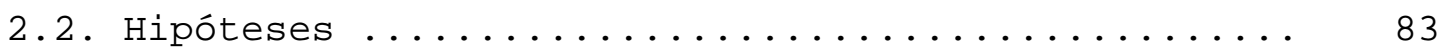

III- Método $\ldots \ldots \ldots \ldots \ldots \ldots \ldots \ldots \ldots \ldots \ldots \ldots \ldots \ldots \ldots \ldots$

3.1. Sujeitos $\ldots \ldots \ldots \ldots \ldots \ldots \ldots \ldots \ldots \ldots \ldots \ldots \ldots \ldots \ldots$. 84

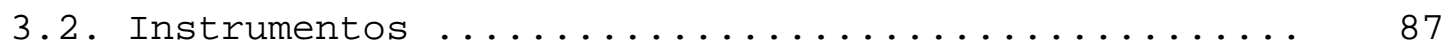

3.2.1. Critério de Classificação Econômica Brasil ... 87

3.2.2 Escala de Locus de Controle de Levenson ....... 89

3.2.3. Escala Geral de Felicidade de Lyubomirsky e Lepper .......................... 90

3.2.4. Questionário de Identificação de Flow ........ 90

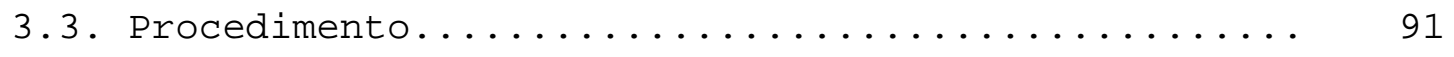

3.4. Considerações Éticas .................... 92 


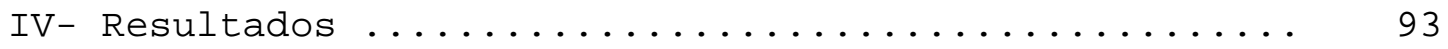

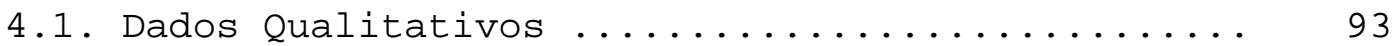

4.2. Dados Quantitativos ................... 94

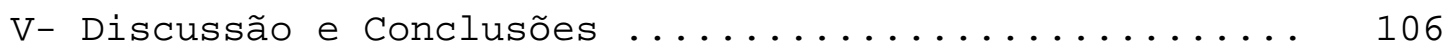

VI - Referências Bibliográficas ................ 111

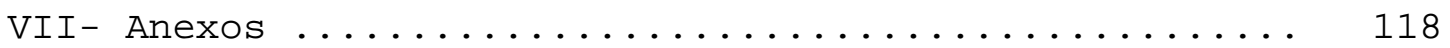


ÍNDICE DE TABELAS

Página

Tabela 1 - Classificação dos Prazeres Maiores .......... 49

Tabela 2 - Comparação entre Prazer e Gratificação ....... 66

Tabela 3 - As Forças Pessoais e suas Relações com as

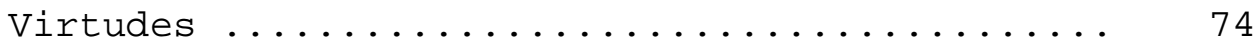

Tabela 4 - Distribuição dos Sujeitos por Idade ......... 84

Tabela 5 - Distribuição dos Sujeitos por Gênero......... 85

Tabela 6 - Classificação Econômica dos Sujeitos ........ 85

Tabela 7 - Sistema de Pontuação CCEB para Posse de Itens . 88

Tabela 8 - Sistema de Pontuação CCEB para Nível de

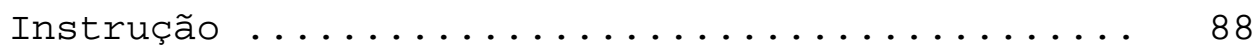

Tabela 9 - Cortes do Critério Brasil ............... 89

Tabela 10 - Estatísticas Descritivas das Variáveis ....... 94

Tabela 11 - Distribuição de Freqüência da Variável

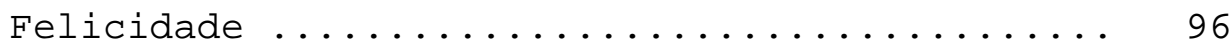

Tabela 12 - Distribuição de Freqüência da Variável Controle Interno .................... 97

Tabela 13 - Distribuição de Freqüência da Variável

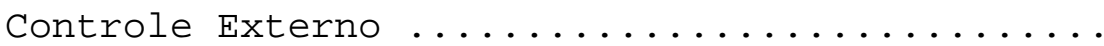

Tabela 14 - Distribuição de Freqüência da Variável Controle do Acaso .................... 98

Tabela 15 - Distribuição de Freqüência da Variável

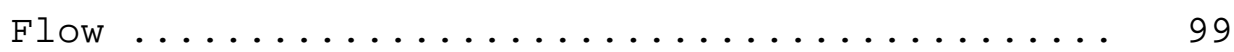

Tabela 16 - Teste Kolmogorov-Smirnov para Aderência à Distribuição Normal ................. 100

Tabela 17 - Correlações de Spearman .................. 101

Tabela 18 - Ranqueamento do Teste Kruskal-Wallis para as Variáveis Controle Interno e Controle Externo, com Respeito à Variável de Grupo Felicidade ... 102

Tabela 19 - Teste $H$ de Kruskal-Wallis para as Variáveis Controle Interno e Controle Externo, com Respeito à Variável de Grupo Felicidade ....... 103 
Tabela 20 - Ranqueamento do Teste Kruskal-Wallis para as Variáveis Controle do Acaso, Flow, NSE, Idade e Sexo, com Respeito à Variável de Grupo Felicidade 104

Tabela 21 - Teste $H$ de Kruskal-Wallis para as Variáveis Controle do Acaso, Flow, NSE, Idade e Sexo com Respeito à Variável de Grupo Felicidade ....... 105 
ÍNDICE DE ANEXOS

Página

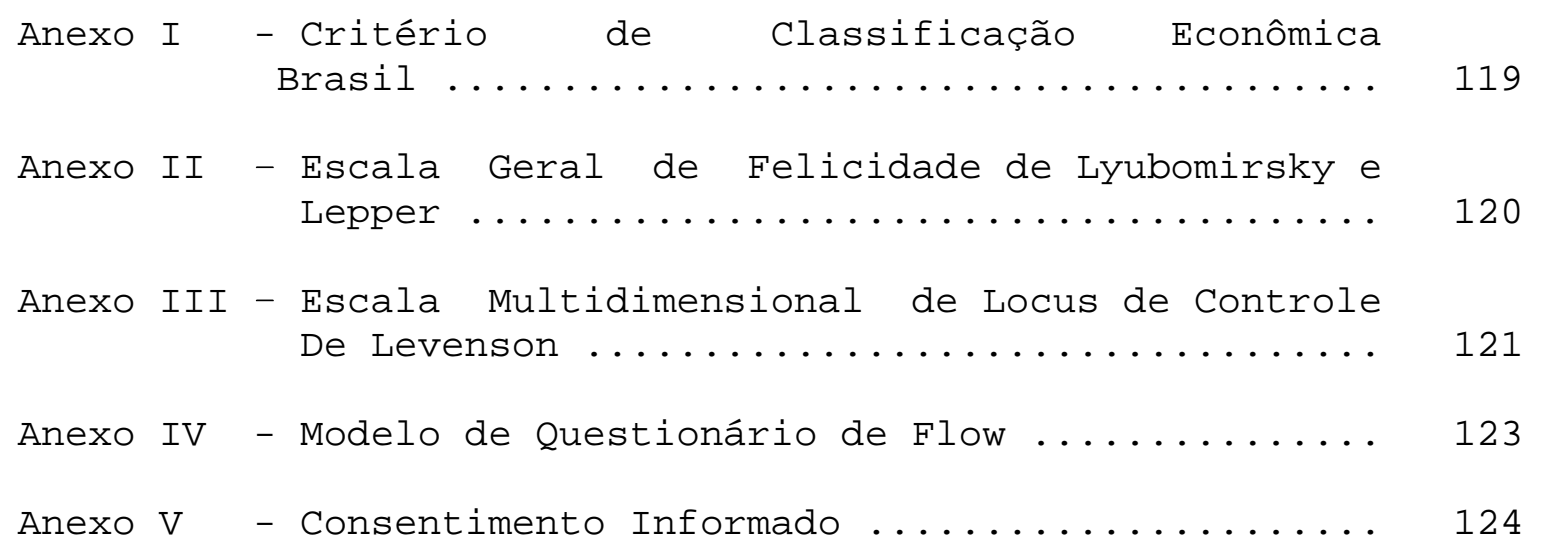


RESUMO

GRAZIANO, L. D. (2005) A Felicidade Revisitada: Um estudo sobre bem-estarsubjetivo na visão da Psicologia Positiva. Tese de Doutorado, 111 pp., Instituto de Psicologia da Universidade de São Paulo, São Paulo.

Pautada no modelo médico, a Psicologia tem direcionado seus esforços científicos muito mais para o estudo dos aspectos disfuncionais do indivíduo do que para suas potencialidades. Isso gerou um desequilíbrio no campo de estudos dessa ciência que, ao focalizar sua atenção quase que exclusivamente nos problemas humanos, acabou por deixar que temas, como a Felicidade, fossem apropriados pela chamada literatura de auto-ajuda. A partir do referencial teórico da Psicologia Positiva, este estudo busca compreender a felicidade humana a partir de uma abordagem científica, o que julgamos fundamental para a construção de um corpo teórico consistente sobre o tema e capaz de auxiliar no desenvolvimento de programas de saúde mental de caráter preventivo. Sendo assim, investigamos a relação entre felicidade e lócus de controle numa amostra de 106 sujeitos universitários utilizando-nos, para tanto da Correlação de Spearman e do Teste de Kruskal-Wallis. Os resultados indicaram que quanto maior o lócus de controle interno dos sujeitos pesquisados, maior também seus níveis de felicidade. 
ABSTRACT

GRAZIANO, L. D. (2005). Happiness Revisited: A study on subjective well-being according to Positive Psychology. Doctoral Dissertation, 111pp., Instituto de Psicologia da Universidade de São Paulo, São Paulo.

Developed around the medical model, Psychology has directed its scientific efforts principally toward the study of the dysfunctional aspects of human behavior rather than toward the potential of the individual. This has created a disequilibrium in the field of study of this science which by focusing its attention almost exclusively on human problems has relegated themes such as Happiness to the so-called self-help literature. Based on the theoretical reference of Positive Psychology, this study seeks to understand Human Happiness from a scientific point of view. We judge this approach fundamental to the construction of a body of theory consistent with the theme and capable of helping in the development of preventive mental health programs. Therefore, we research the relationship between happiness and control "locus" in a sample of 106 university students, using the Spearman Correlation and the KruskalWallis test. The results indicate that the greater the internal control locus of de individuals studied, the greater their level of personal happiness. 
Há muitos anos, quando eu ainda era professora de Literatura, costumava dizer aos meus alunos que a melhor forma de se compreender um texto era através de um mergulho na vida de seu autor. Ainda fiel a este pensamento, pretendo oferecer uma breve explicação acerca do percurso que trilhei até aqui.

Aqueles que ainda crêem no mito da "completa neutralidade científica", talvez julguem minha iniciativa desnecessária. Contudo, acho importante esclarecer a forma como essa pesquisa se encaixa com minha dissertação de Mestrado e o que me motivou a desenvolvê-la.

Talvez seja interessante dizer que, ao ser admitida no programa de doutorado desta Instituição, pretendia trabalhar com um tema bastante diferente do que aquele com o qual tinha me ocupado no Mestrado, o qual havia sido "AIDS e Identidade". Foi necessário um bom tempo (além de alguns contratempos) para que eu compreendesse duas coisas: A primeira delas foi qual a verdadeira razão do meu interesse pelo tema com que trabalhara no Mestrado. E a segunda, é que nessa mesma razão, encontrara a linha de pesquisa da minha vida.

Com a aposentadoria de meu então orientador Prof. Dr. Adail Victorino Castilho no início deste ano, fui "adotada" pela profa. Dra. Maria Isabel Leme que, gentilmente, ajudou-me a (re) encontrar meu caminho, cuja breve descrição farei a seguir:

Em 1996, trabalhando como voluntária numa Instituição que atendia portadores do vírus HIV, acompanhei de perto histórias de dor e perdas de muitos soropositivos: pacientes e amigos com os quais sofri e que muito me ensinaram a respeito da morte e da tristeza que cercava a AIDS. 
Lembro-me de que, para melhor poder ajudá-los, li diversos livros que discutiam o problema da AIDS do ponto de vista psicológico, o que me trouxe importantes chaves de compreensão para o aspecto triste da realidade com a qual convivia. Restava, no entanto, uma parte da realidade sobre a qual ninguém falava e que muito chamou minha atenção: ao invés de cumprir a profecia de ser a grande devastadora da vida emocional dos pacientes, a AIDS, em alguns casos, acabava sendo a alavanca que impulsionava a emancipação das pessoas. Como psicóloga, achava fascinante observar aqueles que, a partir da confirmação do diagnóstico da doença, "passavam suas vidas a limpo", resignificando antigos valores e adotando uma vida de maior qualidade, tornando-se mais felizes. Era como se essas pessoas tivessem, ao abraçar a morte, descoberto o verdadeiro valor da vida. Que capacidade era essa, de não se deixar abater pelas dificuldades, transformando-as em oportunidade para o crescimento? Por que alguns a possuíam e outros não? Seria possível ensinarmos nossos filhos a desenvolvê-la? Entrei no Mestrado interessada em compreender a exceção: aqueles cuja vida emocional a AIDS não conseguira destruir. Naquela época, não conhecia os estudos sobre resiliência, muito menos ouvira falar sobre a Psicologia Positiva que então nascia.

Minha dissertação de Mestrado foi um estudo de caso sobre o processo de construção da identidade de um sujeito cuja emancipação fora provocada pela AIDS. Jamais pensei (nem poderia) generalizar qualquer resultado obtido através daquela pesquisa. A mim bastava mostrar, através da escolha de um sujeito representativo, que aquilo era possível. 
Nos anos seguintes, acabei me especializando no atendimento psicológico em situações críticas, tais como seqüestro, assalto, acidentes, suicídios etc, mantendo sempre um interesse especial naquelas vítimas cujo prognóstico acabava por superar todas as expectativas estabelecidas a partir da intensidade traumática vivenciada. Observei que, invariavelmente, tais pessoas possuíam algo em comum: além de parecerem mais felizes, assumiam uma certa responsabilidade (controle) sobre seu bem-estar, ainda quando esse bem-estar era fortemente ameaçado por eventos externos.

Embora gostasse (como ainda gosto) de trabalhar no sentido de oferecer alguma possibilidade de conforto aos problemas humanos, percebi, finalmente, que minha curiosidade científica sempre esteve mais direcionada para aquilo que torna determinadas pessoas menos suscetíveis a esses problemas. Afinal, minha própria experiência pessoal sempre houvera se contraposto aos prognósticos sugeridos por minha infância e adolescência difíceis. Isso me faz acreditar que existe uma outra via de acesso (além da curativa) para que sejamos capazes de ajudar o ser humano: Já que não podemos (nem devemos) protegê-los das dificuldades, talvez sejamos capazes de ajudá-los a desenvolver habilidades que os auxiliem no confronto diário com a vida.

Em outras palavras, acredito que no dia em que formos capazes de compreender o caráter funcional do comportamento humano tão bem quanto hoje compreendemos o disfuncional, teremos uma verdadeira Psicologia Preventiva e, conseqüentemente, seremos mais felizes. 
Considerações Iniciais

No fundo, sempre me incomodou o fato de ganhar a vida a partir da infelicidade alheia. Ainda que julgue extremamente gratificante (além de fundamental) poder contribuir para a diminuição do sofrimento humano, sempre acreditei que meu dever era também o de oferecer senão condições, ao menos algumas informações que, bem utilizadas, poderiam evitar que, um dia, determinada pessoa precisasse recorrer a uma psicoterapia. Por essa razão, vi muitos de meus amigos de faculdade se espantarem quando tornei-me uma consultora de empresas: Para eles (e confesso que, a princípio também para mim), eu havia me tornado uma psicóloga organizacional, algo impensável para alguém que, desde o primeiro ano do curso, dizia "amar a clínica".

Hoje sei que ao dar uma palestra numa empresa (ou mesmo uma aula na faculdade) sobre qualidade de vida ou gerenciamento de stress, estou não apenas fazendo psicologia preventiva, mas sendo a psicóloga que escolhi ser.

Acredito caber à Psicologia o papel de orientar o homem quanto aos possíveis caminhos que levam à felicidade. Mas, para que isso aconteça, é preciso que nós, psicólogos, tenhamos coragem para voltar nosso olhar científico para um tema que até agora tem sido explorado quase que exclusivamente pela literatura de auto-ajuda. Enquanto isso, a AIDS, o seqüestro, o assalto e o stress, continuarão a ser problemas reais. Mas será que são eles que impedem que o homem contemporâneo seja feliz? Nesse caso, seria possível, por exemplo, que uma pessoa, a partir do diagnóstico da AIDS, encontrasse a felicidade? Em minha dissertação de Mestrado descobri que sim. Mas isso não é o bastante: é preciso compreender melhor a felicidade, suas causas, seus mecanismos e os caminhos que podemos traçar para conquistá-la. 
Como vêem, são muitas as questões a serem respondidas e outras tantas a serem formuladas até que sejamos capazes de dizer o que, de fato, torna um ser humano feliz.

De minha parte, acredito que a pesquisa sobre a relação entre felicidade e locus de controle interno seja um bom caminho. Caminho este cujo início apresentarei neste trabalho. 


\section{I- INTRODUÇÃO}

\subsection{A Psicologia Positiva}

Talvez a melhor maneira de começarmos a falar sobre Psicologia Positiva seja fazendo uma breve análise de seu próprio nome. Considerando a origem etimológica da palavra psicologia, encontramos duas palavras em sua gênese: psiqué e logos. Embora a tradução exata de psiché seja alma, o conceito de alma para o grego está muito mais próximo do que hoje chamamos de mente, visto que a palavra alma acabou impregnada de um caráter quase que exclusivamente religioso. Com relação ao termo logos, sua popularidade talvez dispensasse a necessidade de o traduzirmos como estudo, no entanto, esperamos que o cuidado didático o justifique.

Dessa forma, chegamos ao conhecido significado da palavra psicologia como sendo o estudo da mente, ou mais estritamente, o estudo (sistematizado) da mente humana - considerando que, em última instância, mesmo o estudo do comportamento animal, visa fornecer subsídios para uma maior compreensão acerca do homem.

É de se esperar que a nomenclatura Psicologia Positiva, pressuponha a existência de uma Psicologia negativa. De fato, Seligman (2004) chegou a utilizar este segundo termo para designar uma Psicologia cujo foco tem sido a patologia, o disfuncional e o lado mais sombrio do ser humano.

Retomando o conceito de mente, o dicionário de Psicologia de Corsini (2002, p. 597) traz a seguinte definição: 
Mente: Uma totalidade organizada de processos mentais e psíquicos de um organismo, bem como de componentes estruturais e funcionais dos quais ela depende..

$$
\text { [grifo do autor] [Tradução Livre] }
$$

Se a Psicologia é a ciência que estuda a mente e a mente nada mais é do que a totalidade de nossos processos internos, os termos positivo e negativo deveriam (pelo menos em tese) perder o sentido.

Afinal, a utilização de qualquer um deles seria o mesmo que negar o seu oposto, e, portanto, o mesmo que negar que a mente é formada por um conjunto de medos, angústias, carências, impulsos negativos que convivem ao lado de esperanças, sabedoria, criatividade, coragem, perseverança, dentre outros, formando a chamada afetividade. Sheldon e King (2001) colocam que a Psicologia, ao contrário das outras ciências naturais e sociais, não se preocupa em descrever a estrutura típica e o funcionamento natural de seu tópico de interesse; mais do que isso, criticam que os psicólogos deveriam ser capazes de expressar profunda admiração (como fazem físicos diante da elegância das equações de Einstein) pelo funcionamento humano pleno.

Em suma, a julgar por seu significado mais básico, a Psicologia, enquanto ciência, deveria contemplar toda a complexidade (e diversidade) da mente humana e não apenas de alguns de seus atributos (fossem eles positivos ou negativos). No entanto a necessidade, como veremos, bastante legítima, de um movimento voltado 
para uma Psicologia Positiva, prova que não é isso o que acontece. Nossa Psicologia, ainda pautada no modelo de doença, raramente consegue, na prática, ir tão além quanto suas discussões filosóficas poderiam sugerir, quando o assunto é a compreensão humana.

Para compreendermos melhor as raízes do "desvio de rota" da Psicologia, é necessário voltarmos ao final da Segunda Guerra Mundial. De acordo com Seligman (2004), em 1946 a Psicologia nos Estados Unidos ainda era insipiente e oferecia um campo de atuação profissional restrito. Muitos dos profissionais da época eram acadêmicos que, comprometidos muito mais com uma "ciência pura", procuravam compreender as leis básicas da aprendizagem, motivação e percepção, sem se importar muito com a aplicabilidade do conhecimento que produziam. Ao psicólogo da época, segundo esse mesmo autor, cabiam três missões:

$1^{a}$. Curar a doença mental;

$2^{a}$. Tornar a vida das pessoas comuns mais feliz, mais produtiva e mais plena;

$3^{a}$. Identificar e apoiar jovens excepcionalmente talentosos.

(2004, p.34)

Com relação à primeira missão, Seligman coloca que os psicólogos da época limitavam-se a fazer os testes, ficando a terapia propriamente dita a cargo dos psiquiatras. Já a segunda missão era de responsabilidade dos psicólogos que trabalhavam nas empresas, nas escolas e nos quartéis e a terceira missão dava um grande impulso às pesquisas e ao desenvolvimento de testes de QI.

Foi este cenário que os soldados americanos encontraram, quando voltaram para casa, ao final da Segunda Guerra Mundial. 
E foi exatamente este retorno que abalaria profundamente os alicerces da Psicologia (Seligman \& Csikszentmihalyi, 2000).

Terminados os combates militares, os Estados Unidos sabiam que ainda havia uma outra (e igualmente difícil) batalha a ser vencida: ajudar os veteranos que haviam arriscado suas vidas em combate, a superarem suas seqüelas psicológicas. A demanda por tratamento era enorme e os profissionais que trabalhavam clinicamente (ou seja, os psiquiatras) não seriam suficientes para atendê-la. Além disso, o tratamento oferecido por esses profissionais era muito elitizado e pautado no modelo da psicanálise clássica, com várias sessões semanais, realizadas a um custo muito alto.

Foi então que o Veterans Administration Act de 1946, num verdadeiro "esforço de guerra", ofereceu bolsas de estudos, em nível de pós-graduação, para uma legião de psicólogos que, ao lado dos psiquiatras, tornou-se apta a tratar os veteranos clinicamente. Do tratamento desses veteranos ao atendimento de outros tipos de pacientes, não levou muito tempo, de forma que logo esses psicólogos passaram a ser reembolsados pelas empresas de seguro, dando origem a uma espécie de elite dentro da própria profissão: a dos psicólogos clínicos (ou psicoterapeutas) (Seligman, 2004).

É curioso notar o quanto isso se reflete, ainda hoje, na realidade brasileira. A despeito de um mercado completamente saturado, os cursos de psicologia do Brasil oferecem uma formação preponderantemente clínica, numa mensagem subliminar de que o "verdadeiro psicólogo" é aquele que se dedica à psicoterapia. Mas essa é apenas a ponta do iceberg. 
As conseqüências que o fim da Segunda Guerra traria à Psicologia, enquanto ciência, seriam bem mais sérias:

\begin{abstract}
A psicologia passa a ser praticamente um sinônimo de tratamento de doença mental. Sua missão histórica de fazer a vida das pessoas comuns mais produtiva $e$ plena fica em segundo plano em relação à cura de desordens e às tentativas de identificar e apoiar gênios praticamente abandonados.
\end{abstract}

(Seligman, 2004 p.34)

É esse mesmo autor quem denuncia a criação, pelo Congresso Americano, do Instituto Nacional de Saúde Mental (National Institute of Mental Health) como sendo um mecanismo utilizado para garantir a manutenção dessa tendência na Psicologia, na medida em que, dirigida por psiquiatras, esta instituição passou a financiar apenas pesquisas que demonstrassem sua "significância", ou seja, sua relevância para a causa e a cura das doenças mentais (Idem, 2004).

No caso brasileiro a Psicologia, que até o século XIX se desenvolvera no interior de outras áreas do saber como a Medicina e a Educação, começa, no século $\mathrm{XX}$, a conquistar certa identidade própria, sobretudo pela penetração de idéias e práticas daquilo que na Europa e nos Estados Unidos era considerado como Psicologia científica (Antunes, 2003). Já nas primeiras décadas do século XX, vários psicólogos estrangeiros vieram ao Brasil para ministrar cursos, proferir palestras ou prestar assistências técnicas específicas, sendo que muitos deles acabaram se radicando por aqui (Idem, 2003). 
Isso significa ser perfeitamente razoável supormos que a tendência apontada por Seligman \& Csikszentmihalyi (2000) e Seligman (2004), como conseqüência da Segunda Guerra Mundial, não tenha afetado apenas a Psicologia americana.

É bem verdade que essa forma de conduzir a Psicologia trouxe enormes avanços tanto para a compreensão quanto para o tratamento das doenças mentais. De acordo com Seligman (1994) existem hoje, pelo menos, 14 desordens, antes consideradas intratáveis, tais como depressão, transtorno bipolar e transtorno obsessivo-compulsivo que, por terem sido desvendadas pela ciência, podem agora ser curadas, ou consideravelmente aliviadas; o que, sem dúvida, trata-se de um mérito que não pode ser ignorado. No entanto, é o próprio Seligman (2004) quem nos chama a atenção para o alto preço desse progresso: "ao que parece, o alívio dos transtornos que tornam a vida miserável fez diminuir a preocupação com situações que fazem a vida valer a pena"(p.11).

De qualquer maneira, não podemos dizer que Psicologia Positiva seja simplesmente aquela que objetiva trazer bem-estar ao indivíduo. Se assim fosse, poderíamos dizer que mesmo a Psicologia pautada na doença cumpre, em última instância, esse papel.

Mas, afinal, o que é a Psicologia Positiva? Para Sheldon \& King (2001) trata-se do estudo científico das forças e virtudes próprias do indivíduo, que faz com que os psicólogos adotem uma postura mais apreciativa em relação ao potencial, motivação e capacidades humanas. Para Seligman (2004) trata-se do estudo de sentimentos, emoções, instituições e comportamentos positivos que tem como objetivo final a promoção da felicidade humana. 
Larson (2000) acredita que não se pode dizer que a Psicologia como um todo (e, sobretudo a psicologia do desenvolvimento) tenha negligenciado completamente 0 caráter positivo de seu objeto de estudo, uma vez que o desenvolvimento é, antes de tudo, um processo de crescimento e aumento de competências. No entanto, este mesmo autor sustenta que, no que tange a importantes dimensões do desenvolvimento humano, como o desenvolvimento social e emocional, freqüentemente nos vemos melhor articulados em relação às coisas que dão errado do que com aquelas que dão certo. Como prova de seu raciocínio, aponta os inúmeros estudos voltados ao uso de drogas, violência, suicídio, gravidez na adolescência e outros problemas de comportamento, convivendo ao lado da falta de estudos aplicados rigorosos que indiquem como promover um desenvolvimento positivo.

A tendência da Psicologia atual de priorizar o estudo dos problemas humanos gerou, além do já apontado afastamento de seu significado mais básico, um desequilíbrio no seu campo de estudo e, como veremos mais tarde, talvez até mesmo uma distorção no seu objeto. Para Sheldon \& King (2001) está cada vez mais claro que o funcionamento normal dos seres humanos não pode ser calculado puramente a partir de quadros de referência negativos ou exclusivamente focados nos problemas.

Acreditamos que uma outra conseqüência, da já apontada tendência da Psicologia atual, tenha sido a proliferação da literatura de auto-ajuda.

Preocupada apenas em curar doenças, a Psicologia deixou sem respostas aqueles que questionavam sobre como ter uma vida feliz, abrindo espaço para que as forças e virtudes humanas fossem discutidas sem base científica e, por vezes, de 
maneira hiper-simplificada. De acordo com Seligman \& Csikszentmihalyi (2000), foi também a ausência de base empírica suficiente, a grande responsável pela falha das teorias "ancestrais" da Psicologia Positiva, como o Humanismo, por exemplo, em fazer com que esta tendência, efetivamente, se firmasse.

O foco inicial da Psicologia Positiva é exemplificado através do trabalho de pioneiros tais como Terman, Jung e Watson que, na década de 30, publicaram estudos sobre superdotados, sucesso no casamento e paternidade efetiva, respectivamente. Além disso o próprio trabalho de Jung sobre a procura e descoberta de significado na vida constitui-se num bom exemplo. (Seligman \& Csikszentmihalyi, 2000). Portanto, é necessário lembrar que iniciativas como estas devem ser reconhecidas e, sobretudo, não permitem que a Psicologia Positiva reclame para si o atributo de originalidade (Idem, 2000), o que, vale dizer, em nada diminui sua relevância.

No entanto, o movimento científico batizado de Psicologia Positiva surgiu nos Estados Unidos, em janeiro de 1998 a partir da iniciativa de Martin Seligman que, ao lado de renomados cientistas como Mihaly Csikszentmihalyi, Ray Fowler, Chris Peterson, George Vaillant, Ed Diener dentre outros, começou a desenvolver pesquisas utilizando o método científico quantitativo, a fim de promover uma mudança de foco na Psicologia atual - do estudo de algumas das piores coisas da vida para o estudo do que faz com que a vida valha a pena (Seligman, 2004).

Um dos maiores desafios da Psicologia Positiva é lutar contra o que Seligman (2004) chamou de "dogma imprestável", ou seja, contra a cultura da Psicologia atual 
que apenas considera como autênticas (verdadeiras e válidas), as emoções negativas. Nesse sentido, vale ressaltar que, ao falarmos de uma "Psicologia atual", não estamos negando o caráter fragmentário do corpo teórico dessa Ciência que, segundo Mahoney (1989) era, até então, composto por mais de 700 linhas diferentes. Por outro lado, a utilização de uma terminologia que sugere se tratar a Psicologia de uma Ciência única, justifica-se devido ao fato de compreendermos a Psicologia Positiva como uma crítica ao uso do modelo médico, ou seja, de um modelo pautado na doença e no aspecto disfuncional do ser humano, o qual podemos verificar em várias linhas teóricas diferentes. Além disso, a expressão "Psicologia Atual" refere-se a uma tendência geral, o que, eventualmente, pode excluir determinadas abordagens.

Outro esclarecimento necessário diz respeito ao uso que a Psicologia Positiva faz dos termos "positivo" e "negativo" para qualificar as emoções. Devemos entender as chamadas "emoções positivas" como sendo aquelas que favorecem a aproximação, e conseqüentemente, a convivência com o outro, enquanto que as "emoções negativas" fazem o contrário (Fredrickson, 2001).

O biólogo Humberto Maturana $(2001,2002)$ afirma que não é a razão, e sim a emoção que nos leva a agir e interagir com o outro. Para ele, estas interações se apresentam em dois tipos: as que "ampliam e estabilizam a convivência" (2002, p.22) e as que "interferem e rompem a convivência" (2002, p. 22). Embora não chegue a utilizar os termos "positivo" e "negativo" para qualificar as emoções que embasam estas interações, Maturana (2002) aponta o amor como responsável pelas interações do primeiro tipo, ou seja, por aquelas que ampliam e estabilizam a convivência, ao passo que a agressão seria a responsável pelas interações que rompem a convivência. 
Ainda de acordo com este autor, o amor (portanto, uma emoção positiva) se faz tanto mais necessário quanto mais complexas forem as sociedades.

... a história dos insetos sociais se inicia quando as fêmeas tratam seus ovos como companhia legítima numa relação de aceitação mútua, e se constitui com a formação de uma linhagem na qual essa relação de interações de aceitação mútua se conserva como modo de viver, e se amplia às larvas e adultos

Nesse sentido, e como conseqüência do legado de complexidade deixado pela Revolução da Informação, o desenvolvimento de pesquisas em Psicologia Positiva talvez se torne uma questão de sobrevivência. É preciso que temas como virtude, caráter e felicidade humana sejam discutidos de forma secular, produzindo um conhecimento capaz de transpor os portais das igrejas e a superficialidade dos manuais de auto-ajuda, de forma a que todos possam crer - aqui e agora - na sua existência.

Isto posto, podemos retomar a questão do "dogma imprestável”, que, conforme já dissemos, refere-se a uma tendência de o olhar psicológico considerar como autênticas apenas as emoções negativas. Sheldon \& King (2001) corroboram essa idéia, dizendo que, ao observarem alguém ajudando uma pessoa estranha, é comum que os psicólogos rapidamente encontrem um benefício egoísta no ato, relutantes em reconhecer a existência do altruísmo. Martin Seligman, que foi presidente da American Psychological Association, acrescenta, ainda, que, para que uma análise psicológica seja academicamente respeitável, "a bondade tem de estar assentada sobre um motivo oculto e negativo" (2004, p.13). Deixando de lado o juízo de valor 
que possa estar implícito na palavra negativo desta citação, concordamos com o autor no sentido de a motivação da bondade ser, costumeiramente, analisada pela Psicologia como tendo suas raízes no interesse próprio de quem a pratica, ainda que tal interesse não seja material.

Por mais que sejamos culturalmente propensos a aceitar esse "dogma imprestável”, não há o menor indício de que as forças e virtudes humanas tenham, de fato, este tipo de motivação. Nesse sentido, parece mais razoável partirmos de uma premissa de duplo aspecto que acredita que a evolução tenha favorecido tanto as más quanto as boas qualidades humanas (Idem, 2004).

Neste ponto talvez seja necessário um esclarecimento acerca daquilo que a Psicologia Positiva chama de boas e más qualidades. Partindo da idéia de que seriam positivas as emoções que favorecem a interação e negativas aquelas que a prejudicam, a Psicologia Positiva chamou de "boas qualidades" as características humanas que favorecem as emoções positivas e o comportamento de interação, de forma que as más qualidades seriam o oposto, ou seja, as características humanas que favorecem as emoções negativas, bem como o comportamento que prejudica a interação.

Embora saibamos não ser intenção da Psicologia Positiva negar a funcionalidade das emoções e qualidades as quais denomina negativas, reconhecemos que tal nomenclatura é capaz de sugerir um juízo de valor que prejudicaria a compreensão correta do conceito, o que justifica nosso cuidado ao descrevê-lo. 
Se por um lado, a evolução das más qualidades parece claramente se justificar pela necessidade de adaptação a um ambiente hostil e por um instinto de autopreservação, o mesmo não ocorre em relação às boas qualidades do ser humano. Afinal, para quê ajudar o outro, se isto pode fortalecê-lo e fazer com que sejamos nós o elo mais fraco, cuja sobrevivência será ameaçada pelos mais aptos? Por muito tempo esta pergunta permaneceu sem resposta, contribuindo, talvez, para que apenas as más qualidades humanas fossem consideradas autênticas.

No entanto, pesquisas recentes parecem, finalmente, ter encontrado um sentido para as emoções positivas (e por extensão, para as boas qualidades) dentro do processo evolutivo. De acordo com Fredrickson (2001), as emoções positivas fortalecem nossos repertórios físicos, sociais e intelectuais, criando recursos dos quais podemos lançar mão quando uma oportunidade ou ameaça ambiental se apresentam. Além disso, esta autora afirma que o estado de espírito positivo desperta a afetividade do outro, criando um ambiente favorável, além de contribuir para o desenvolvimento da resiliência ${ }^{1}$ psicológica que, por sua vez, desencadeia uma espiral ascendente em direção à melhoria do bem-estar emocional. Isso nos leva a crer que, do ponto de vista do desenvolvimento humano, um funcionamento ótimo jamais poderia prescindir das emoções positivas, sobretudo se considerarmos o fato de hoje nos encontrarmos, graças aos avanços tecnológicos, cada vez mais expostos a culturas diferentes e por que não dizer, até mesmo dependentes delas.

\footnotetext{
${ }^{1}$ De acordo com Reivich \& Shatté, corresponde à "habilidade de perseverar e se adaptar quando as coisas dão errado" (2002, p.1 [tradução livre]). Em outras palavras, poderíamos definir resiliência como sendo uma capacidade para tolerar frustrações, sem desistir de seus objetivos.
} 
Fenômenos como o da globalização expõem o homem contemporâneo a um ambiente que clama por emoções positivas com uma urgência jamais vista em nenhum outro momento da evolução.

Massimini e Delle Fave (2000), reconhecendo a existência de uma tendência à aculturação que ocorre quando duas culturas de níveis de desenvolvimento diferentes se encontram, apontam para o risco de que, num mundo globalizado, a cultura menos desenvolvida economicamente venha a ser extinta, não somente pela ação direta da cultura dominante, mas também como resultado de uma estratégia de autopreservação retratada na adoção, por parte da cultura menos desenvolvida, de uma postura de reclusão cultural. Dessa forma, esses autores apontam a seleção bicultural como sendo a estratégia mais adaptativa, sobretudo quando estabelecida nas ações diárias que visam permitir a integração dos indivíduos a um ambiente em permanente mudança. Nessa mesma linha, Marsella (1998) propõe o desenvolvimento de uma Psicologia Global-comunitária, uma meta-teoria psicológica, definida a partir de uma série de premissas, métodos e práticas psicológicas, edificados sobre fundamentos multiculturais, multidisciplinares, multisetoriais e multinacionais que seriam de interesse, escopo, relevância e aplicabilidade globais. De que outra forma seria isso possível, senão pelo cultivo de emoções positivas?

Nesse sentido, Wright (2000) vai ainda mais longe, ao sugerir que o segredo da vida está no jogo com soma diferente de zero. Para ele, os sistemas biológicos são forçados pela seleção darwiniana na direção de mais complexidade e mais situações em que todos saiam ganhando, como atesta a supremacia da célula que incorpora simbioticamente a mitocôndria em relação àquelas que não são capazes de fazê-lo. Mas não é apenas a mudança biológica que assume essa direção. 
Segundo esse mesmo autor, o mesmo ocorre em relação à história da humanidade, visto que o cenário universal da mudança política vai do selvagem ao bárbaro e daí à civilização, numa progressão que traz em seu âmago um aumento não só de complexidade, mas de situações em que todos saem ganhando. Ou seja, quanto mais jogos de soma positiva houver em uma cultura, maiores suas chances de sobrevivência e desenvolvimento (Idem, 2000).

Esses aspectos talvez já fossem suficientes para justificar não apenas a necessidade de uma Psicologia Positiva, mas, principalmente, do desenvolvimento de pesquisas nessa área. Contudo, a Psicologia Positiva tem ainda o mérito de resgatar o caráter preventivo que, há muito, fora abandonado por uma Psicologia focada exclusivamente na doença. Através do estudo das características humanas positivas, a ciência aprenderá a prevenir doenças físicas e mentais e os psicólogos, por sua vez, aprenderão a desenvolver qualidades que ajudem indivíduos e comunidades a, muito mais do que apenas resistir e sobreviver, efetivamente, florescer (Seligman \& Csikszentmihalyi, 2000).

Diante da dificuldade de acesso do brasileiro médio à psicoterapia, esta ênfase na Psicologia curativa torna-se um contra-senso. Nesse sentido, pesquisas na área da Psicologia Positiva são ainda mais úteis para o desenvolvimento de políticas de promoção da saúde mental não apenas entre as comunidades carentes, mas junto à sociedade como um todo.

De acordo com Seligman (2004) a Psicologia Positiva está pautada sobre 3 pilares: 
a-) O estudo da emoção positiva;

b-) $O$ estudo dos traços ou qualidades positivas, principalmente forças e virtudes, incluindo também habilidades como inteligência e capacidade atlética;

c-) O estudo das chamadas instituições positivas, como a democracia, a família e a liberdade (que dão suporte às virtudes que, por sua vez, apóiam as emoções positivas).

Ao focarmos este estudo em aspectos como felicidade e locus de controle, apoiaremo-nos no primeiro pilar apontado, muito embora reconheçamos a importância dos outros dois.

Finalmente, vale dizer que acreditamos que o papel de uma Psicologia que se auto-denomina positiva, muito antes de promover (mais) uma cisão no corpo teórico desta disciplina seja, simplesmente, o de fazer um contraponto, promovendo o equilíbrio entre a compreensão dos problemas e das potencialidades humanas. Acreditamos, ainda, que, no momento em que tal equilíbrio se efetivar, a denominação positiva perderá seu sentido e deixará claro que a Psicologia Positiva, na verdade, nunca foi nada mais do que, apenas, Psicologia. 


\title{
1.1.2. A Felicidade Humana
}

\author{
"Toda gente, meu irmão Gallion, \\ deseja uma vida feliz; mas quando se \\ trata de ver claramente aquilo que a \\ torna assim, é a confusão total" \\ Sêneca, 262 a.C \\ "... e toda dor vem do desejo de \\ não sentirmos dor". \\ Renato Russo, 1990
}

Talvez não seja exagero imaginarmos que a busca pela felicidade tenha sido a grande mola propulsora a conduzir a espécie humana em sua trajetória pelo mundo. Da invenção da roda à clonagem humana, apenas uma coisa se manteve atual: o desejo por uma vida melhor. De qualquer forma, conforme atesta a Filosofia, a preocupação humana com a felicidade é bastante antiga. Aristóteles que viveu de 384 a 322 a.C., acreditava na felicidade como objetivo de todo homem, o qual só seria atingido através do exercício das virtudes, em sintonia com a vida em sociedade (Aristóteles, Ética a Nicômaco, 1987). Arrancando o homem do arbítrio dos deuses e do fatalismo das leis naturais, Epicuro (341 a 270 a.C.) afirma que lhe é possível levar uma existência feliz através da recusa dos excessos, medos e compromissos que podem levar a sofrimentos inúteis (Epicuro, Carta sobre a Felicidade, 1994). Sêneca (ano 2 a.C. a 65 d.C.) observando sua sociedade bastante infeliz, recusava-a como padrão de referência, dizendo que para ser feliz, a primeira coisa que o indivíduo deveria fazer seria recusar-se seguir a multidão (Sêneca, Da vida feliz, 1997).

Já no século XX, mais especificamente falando, na década de 30 , o filósofo 
Bertrand Russel acreditando na felicidade como um bem a ser conquistado e não como uma dádiva divina, aponta para a importância de o homem integrar-se com a sociedade, buscando a felicidade de outrem na mesma medida em que busca a sua própria (Russel, 2003).

Em uma perspectiva mais contemporânea, temos a análise histórica de Delumeau (1997) acerca da felicidade, através da qual afirma que os séculos XIX e $\mathrm{XX}$ foram invadidos por uma onda de pessimismo que, iniciada em Shopenhauer, foi disseminada através das idéias de Nietzsche e Freud, acabando por dominar boa parte do pensamento filosófico durante todo o século XX.

A julgar por sua grande influência no pensamento ocidental, talvez devamos a Freud o abandono do que chamaríamos de projeto da felicidade. Em sua obra "Além do princípio do prazer" Freud (1998, [1920]) discorre sobre o que chamou de instinto de morte, contestando que o objetivo da vida pudesse ser alcançar um estado que jamais fora alcançado antes. Acreditando na essência humana como algo eminentemente ruim, Freud condenou o homem a uma angústia eterna, sofrendo numa luta igualmente eterna para manter sua essência sob controle.

Ainda sob uma perspectiva histórica, podemos observar que a concepção humana de felicidade esteve sempre baseada em dois tipos de premissas excludentes: uma de natureza extrínseca e outra de natureza intrínseca. A premissa que crê na natureza extrínseca da felicidade leva o indivíduo a buscá-la para além de si mesmo, não necessariamente de uma forma comodista mas, certamente, com a expectativa de encontrá-la em eventos ou conquistas externas a sua pessoa. 
Como exemplo dessa concepção podemos citar o milenarismo² (Delumeau, 1997), por ver a felicidade como conseqüência da vinda do Cristo; o iluminismo (Idem, 1997) por tê-la como conseqüência do progresso e o próprio hedonismo, por acreditar que o segredo da felicidade consiste no aumento dos bons e diminuição dos maus momentos da vida. Para os que se baseiam nesse tipo de premissa, a sociedade contemporânea não parece ter muito a oferecer: terrorismo, guerras, epidemias, violência urbana, desemprego são apenas alguns dos exemplos daquilo com que temos de conviver atualmente, de modo que vincular nossa felicidade a sua eliminação, ou mesmo diminuição, seria o mesmo que abrir mão de uma vida feliz.

A concepção de felicidade que parte de uma premissa intrínseca, vê o próprio indivíduo como sua fonte, conferindo a ele a tarefa de trabalhar a si mesmo de forma a conquistar uma vida feliz. Como exemplo desse tipo de concepção podemos citar a teoria de Aristóteles que via a felicidade como resultado do exercício das virtudes; a de Epicuro que pregava o controle dos excessos como forma de evitar o sofrimento e a teoria de Sêneca que dizia ser feliz a alma livre, que desdenha dos golpes da sorte e encontra o seu contentamento na virtude. Se para alguns esta concepção de felicidade parece bem mais animadora, para outros pode parecer desconcertante, afinal, torna-se difícil explicar que o mesmo homem que criou a inteligência artificial não seja capaz de viver uma vida feliz.

De acordo com La Taille (2002), a felicidade ou a vida boa no sentido filosófico seria alcançada pelo exercício daquilo que o indivíduo considera virtuoso e digno de consideração.

\footnotetext{
${ }^{2}$ Crença na segunda vinda de Cristo à Terra, quando se iniciaria um período de 1000 anos de felicidade.
} 
Nesse sentido, este autor utiliza a expressão "ferida moral" para designar a consciência deste indivíduo de saber-se merecedor do desprezo de outrem (Idem, 2002).

Partindo de uma concepção de felicidade de natureza intrínseca, a Psicologia Positiva, embora não negue a influência de eventos externos, trabalha com o conceito de bem-estar subjetivo que corresponde à avaliação, tanto cognitiva quanto afetiva, que uma pessoa faz acerca de sua própria vida (Diener, Lucas \& Oishi, 2002). Dessa forma, trata-se de um conceito amplo que inclui: experiências emocionais agradáveis, baixos níveis de humores negativos e alta satisfação em relação à vida (Idem, 2002). Já a palavra felicidade é usada como termo abrangente que descreve o conjunto de metas da Psicologia Positiva, conforme explica Seligman:

A palavra em si não é um termo da teoria (ao contrário de prazer e flow, que são entidades quantificáveis com respeitáveis propriedades psicométricas, isto é, demonstram certa estabilidade em relação ao tempo e confiabilidade entre os observadores). Felicidade, enquanto termo, é como cognição, no campo da Psicologia cognitiva, e como aprendizagem, dentro da teoria da aprendizagem: dão nome a um campo, mas não exercem qualquer papel nas teorias, dentro daqueles campos.

(2004, p. 333)

Vale dizer que, para fins deste estudo, tomaremos os termos felicidade e bemestar-subjetivo como sinônimos. Isto porque não acreditamos que haja uma felicidade além daquela percebida (subjetivamente, é claro) pelo indivíduo. 
Os estudos empíricos sobre bem-estar subjetivo começaram a tomar forma já no início do século XX através de pesquisas como a de Flugel (1925) que estudou os humores, solicitando às pessoas que recordassem seus eventos emocionais em diferentes momentos. Após a Segunda Guerra, pesquisadores como George Gallup, Gerald Gurin e Hadley Cantul conduziram pesquisas de levantamento de larga escala através das quais estudaram a felicidade e a satisfação em relação à vida, utilizando questionários de levantamento global (Diener, Lucas \&Oishi, 2002), ou seja, que mediam a felicidade como um todo.

Talvez num dos mais importantes estudos no campo do bem-estar, Bradburn (1969) mostrou que os sentimentos de prazer e desprazer são relativamente independentes, não sendo simples opostos um do outro. Para Diener, Lucas \& Oishi (2002) esta descoberta tem importantes implicações para o campo do bem-estar subjetivo, na medida em que mostra que as tentativas da Psicologia clínica em eliminar os estados negativos não é capaz de promover, necessariamente, estados positivos; em outras palavras, podemos dizer que, uma Psicologia focada na remissão ou alívio do sofrimento, embora importante, não é capaz de promover a felicidade humana.

Mais recentemente, Diener (2000) propôs que um índice nacional fosse criado, a fim de que se pudesse medir o bem-estar subjetivo através do tempo, fornecendo dados sobre os quais pudessem ser definidas políticas e ações públicas para o aumento da felicidade da sociedade.

O campo do bem-estar subjetivo enquanto disciplina científica tem crescido rapidamente (Diener, Lucas \&Oishi, 2002). 
Trata-se de um crescimento que se justifica devido ao fato de estarmos entrando num mundo pós-materialista, no qual mais do que na prosperidade econômica, as pessoas têm se interessado por questões relativas à qualidade de vida; além disso o bem-estar subjetivo deve sua popularidade ao fato de ser particularmente democrático, ou seja, por respeitar o que as pessoas pensam sobre suas próprias vidas; e, finalmente, podemos dizer que o estudo do bem-estar subjetivo floresceu devido ao crescimento do individualismo ao redor do mundo, pois o fato de os individualistas estarem preocupados com seus próprios sentimentos e crenças, coloca os estudos do bem-estar subjetivo em perfeita sintonia com a cultura ocidental (Diener, Lucas \&Oishi, 2002).

Embora as pessoas façam julgamentos sobre suas vidas como um todo, o bemestar subjetivo possui, de acordo com Diener $(1984,2000)$ e Diener at all (1999), diferentes componentes:

- Satisfação com a vida: Corresponde aos julgamentos que se faz em relação à própria vida;

- Satisfação em áreas importantes: Satisfação em diferentes domínios, tais como o trabalho, por exemplo;

- Emoções positivas: Muitas experiências de emoções e humores agradáveis;

- Baixos níveis de emoções negativas: Experiência de poucas emoções e humores desprazeirosos. 
Vale observar que, ao descrever os componentes do bem-estar-subjetivo, Diener (2000) analisa as emoções positivas e negativas do ponto de vista daquele que as experimenta, chamando de positivas as emoções agradáveis e negativas as que the são desprazeirosas. Dentro desse raciocínio, o autor não deixa claro se as emoções que favorecem a interação (emoções positivas) seriam sempre agradáveis de serem sentidas, ao passo que as emoções negativas (que levam ao afastamento) sempre provocassem desprazer.

O que poderíamos dizer é que, de fato, emoções negativas como raiva, medo, tristeza, ansiedade, em geral, causam desconforto para aquele que as experimenta, o mesmo não ocorrendo em relação às emoções positivas.

Dessa forma, as pesquisas no campo da felicidade tanto podem investigar esses componentes separadamente, quanto podem usar medidas globais para avaliar o bem-estar subjetivo.

Para Diener, Lucas \&Oishi (2002), as teorias sobre felicidade podem ser categorizadas em três grupos: teorias de satisfação de necessidades e objetivos, teorias de processo ou atividade e teorias de predisposição genética e personalidade.

As teorias de satisfação de necessidades giram em torno da idéia de que a redução de tensões - como eliminação da dor e satisfação das necessidades biológicas - leva à felicidade.

Para as teorias de processo ou atividade, a felicidade é o resultado do engajamento em atividades específicas. Nesse sentido, podemos compreender mais facilmente o caso do sujeito com o qual trabalhamos no Mestrado e que, a partir do diagnóstico da AIDS, transformou-se num militante da causa, o que, por sua vez, acabou fazendo dele uma pessoa mais feliz (Graziano, 1998). 
Ainda neste mesmo grupo teórico, destaca-se a teoria do flow (Csikszentmihalyi, 1992), que discutiremos melhor no capítulo seguinte, e segundo a qual a felicidade é conquistada através do engajamento em atividades desafiadoras que coincidem com o nível de habilidade do indivíduo.

Conforme vimos, se considerarmos os dois grupos de teorias mencionados, podemos dizer que as pessoas experimentam bem-estar quando estão se aproximando de seus objetivos ou engajadas em atividades interessantes. Isso significa que para ambos os grupos, as condições de vida exercem uma grande influência no bem-estar subjetivo (Diener, Lucas \&Oishi, 2002). Porém tal influência não é suficiente para que encontremos uma relação direta entre variáveis tais como prosperidade e felicidade (Csikszentmihalyi, 1999). É possível notar que há um elemento de estabilidade nos níveis de bem-estar das pessoas, que não pode ser explicado através da estabilidade das condições sob as quais elas vivem. Estudos com ganhadores de loterias levaram Brickman, Coates \& Bulman (1978) a concluírem que estes não eram mais felizes do que o grupo controle, formado por pessoas que não haviam ganhado prêmio algum. Isso leva a crer que o bem-estar subjetivo é fortemente influenciado por disposições de personalidade estáveis que refletem a tendência do indivíduo ao reagir cognitiva e emocionalmente em relação às circunstâncias da vida (Diener, Lucas \& Oishi, 2002). As teorias de felicidade que trabalham sob esse enfoque são chamadas de teorias de predisposição genética e personalidade.

Seligman (2004) faz uma distinção entre o que chama de "felicidade momentânea” e os níveis constantes de felicidade do indivíduo. 
Contudo, preferimos, assim como Diener, Lucas \&Oishi (2002) falar em bemestar subjetivo momentâneo e de longo-prazo para diferenciar os momentos de felicidade episódicos dos níveis mais constantes de felicidade que se pode experimentar.

Seligman (2004) afirma que o bem-estar subjetivo momentâneo - o qual chama de felicidade momentânea - pode ser facilmente aumentado através de artifícios simples como "chocolate, uma comédia de cinema, uma massagem nas costas, um cumprimento, flores ou uma roupa nova" (p. 61). Da forma como são descritos, tais artifícios se mostram intimamente ligados ao prazer e talvez seja exatamente por isso que eles se mostram tão pouco eficientes na promoção do bem-estar de longo prazo, conforme explicaremos melhor no capítulo seguinte.

Embora seja difícil prever o quão feliz um indivíduo será num dado momento, quando tiramos uma média das emoções em várias situações diferentes, padrões estáveis de diferenças individuais aparecem (Diener, Lucas \&Oishi, 2002). Através de uma pesquisa que investigava a estabilidade temporal das emoções em diferentes contextos, Diener e Larsen (1984) descobriram que, na amostra estudada, os níveis médios de prazer experienciado nas situações de trabalho apresentaram uma correlação de .74 com os níveis médios de prazer experienciados em situações de recreação; da mesma forma como os níveis médios de satisfação com a vida em situações sociais correlacionaram-se em .92 com a média de satisfação com a vida quando os sujeitos se encontravam sozinhos.

Além disso Magnus \& Diener (1991 apud Diener, Lucas \&Oishi, 2002) através de um estudo longitudinal, encontraram uma correlação de .58 entre medidas de satisfação com a vida num intervalo de quatro anos. 
De acordo com Seligman (2004) em menos de três meses, eventos importantes, sejam eles positivos ou negativos, perdem o impacto sobre os níveis de bem-estar subjetivo, fazendo com que as pessoas voltem a apresentar seus níveis médios de felicidade.

Uma razão para a estabilidade e consistência do bem-estar subjetivo é que há um componente genético substancial nele, ou seja, em algum grau as pessoas nascem prontas para serem felizes ou infelizes (Diener, Lucas \&Oishi, 2002).

Depois de compararem similaridades entre gêmeos monozigóticos e dizigóticos, Tellegen (1988) e seus colegas estimaram que 40\% da variabilidade em emoções positivas e 55\% da variabilidade em emoções negativas podem ser previstas pela variação genética. Embora tais estimativas estejam sujeitas a influências ambientais, os genes realmente parecem influenciar as respostas emocionais características às circunstâncias da vida (Diener, Lucas \&Oishi, 2002).

Com o objetivo de explicar a felicidade humana, Seligman (2004) propõe a seguinte fórmula: $\mathrm{H}=\mathrm{S}+\mathrm{C}+\mathrm{V}$ onde $\mathrm{H}$ (happiness) corresponde ao nível de felicidade constante, $S$ (set range) são os limites estabelecidos aos quais o sujeito está submetido, C (circumstances) são as circunstâncias da vida e V (voluntary) representa os fatores que estão sob o controle voluntário do indivíduo. Através dessa fórmula, percebemos que a visão da Psicologia Positiva sobre a felicidade abrange os três grupos teóricos citados, na medida em que reconhece tanto a influência da satisfação pelo atingimento de objetivos e suprimento de necessidades quanto através da realização de determinados tipos de atividade, isto tudo sem negar a mediação genética na experiência do bem-estar subjetivo. No entanto devemos considerar as palavras de Seligman: 
A felicidade, que é o objetivo da Psicologia Positiva, não se resume a alcançar estados subjetivos momentâneos. Felicidade também inclui a idéia de uma vida autêntica (...) e autenticidade descreve $o$ ato de obter gratificação e emoção positiva através do exercício das próprias forças pessoais, que são caminhos naturais e permanentes para a gratificação.

(2004, p. 288)

Nesse sentido acreditamos que a compreensão tanto da gratificação quanto das chamadas forças pessoais sejam fundamentais para que sejamos capazes de conhecer melhor os caminhos que levam tanto à felicidade quanto ao bem-estar subjetivo. Por essa razão, dedicaremos os próximos capítulos ao estudo desses conceitos. 


\subsubsection{Prazer e Gratificação}

na Psicologia Positiva

$\mathrm{Na}$ cultura ocidental é comum encontrarmos os termos prazer e gratificação usados como sinônimos. No entanto, a utilização indistinta dos termos talvez chegue mesmo a justificar boa parte da dificuldade humana para atingir aquilo que chamamos de felicidade. De acordo com Seligman (2004) há duas maneiras de experimentarmos a felicidade no momento presente: através do prazer e através da gratificação. Para este autor, prazeres são definidos como sendo satisfações com claros componentes sensoriais e fortemente emocionais, que se caracterizam por serem passageiras e exigirem pouco ou mesmo, nenhum, raciocínio. Nesse sentido, definimos como prazer: o êxtase, o entusiasmo, o orgasmo, o deleite, o gozo, a exuberância e o conforto.

Já a gratificação, por sua vez, não é acompanhada, necessariamente, por qualquer sensação natural e se origina das atividades que gostamos muito de praticar e que nos envolvem, de tal forma, que perdemos a noção da realidade. Durante tais atividades, sentimos que nossas habilidades atendem ao desafio do que estamos fazendo e entramos em contato com nossas forças pessoais (Idem, 2004). Uma boa conversa, a leitura de um livro e a escalada de uma montanha são exemplos de atividades que podem levar à gratificação.

Vejamos melhor como estas duas emoções se diferenciam e como cada uma delas se relaciona com a conquista de uma vida feliz. 


\section{O Prazer:}

Em nossa cultura é comum ouvirmos depoimentos de pessoas que, inquiridas acerca da felicidade que possuem, respondem com o jargão: "felicidade são momentos". Interessante observar que, ao lado de tal declaração, é quase sempre possível identificarmos um certo desapontamento, talvez gerado pela frustração de uma felicidade tão fugidia. Não dispomos de dados científicos (nem se trata do foco desta pesquisa) para analisarmos se existe ou não tal desapontamento e se este é ou não conseqüência do que apontamos. No entanto, acreditamos ser razoável supor que aqueles que não acreditam na felicidade em termos absolutos, talvez estejam, como veremos a seguir, confundindo-a com prazer. Para definir o prazer, Csikszentmihalyi (1992) afirma:

O prazer é uma sensação de contentamento que atingimos sempre que a informação da consciência diz que as expectativas estabelecidas pelos programas biológicos ou pelo condicionamento social foram satisfeitas.

Nesse sentido, tomar um banho relaxante após um dia cansativo, fazer uma boa refeição quando se está com fome ou mesmo viajar para a Europa nas férias, costumam ser importantes fontes de prazer e negar seu potencial de satisfação seria o mesmo que negar sua contribuição para aquilo que chamamos de qualidade de vida. A partir de sua complexidade, bem como do tipo de satisfação que proporcionam, chegamos a muitas formas diferentes de prazer. 
Contudo, não podemos imaginar que, por si só, o prazer seja capaz de trazer felicidade (Csikszentmihalyi, 1992).

Em linhas gerais, os prazeres se caracterizam por uma duração efêmera, o que explicaria a já mencionada crença de algumas pessoas que, ao confundirem felicidade com prazer, sustentam a impossibilidade de se conquistar a felicidade senão por uns poucos momentos. A maior dificuldade em se construir a vida em torno de prazeres é justamente seu caráter passageiro. "Assim que o estímulo cessa, eles [os prazeres] desaparecem rapidamente" (Seligman, 2004 p. 123).

Uma outra característica do prazer é sua incapacidade de promover o crescimento psicológico e trazer complexidade ao self, pois embora ajude a manter a ordem da consciência, não é capaz, por si só, de nela estabelecer uma nova ordem (Csikszentmihalyi, 1992). Por estar mais ligada ao conceito de gratificação, a questão da complexidade do self será melhor discutida mais adiante, a fim de facilitar a compreensão do leitor.

De acordo com Seligman (2004), os prazeres se dividem em prazeres físicos e prazeres maiores. Os prazeres físicos permitem satisfação imediata e mantêm estreita ligação com os órgãos dos sentidos. A visão de um campo florido, o já citado banho quente ao final de um dia de trabalho, um gole de um bom vinho, o toque das mãos da pessoa amada em nosso rosto são bons exemplos de situações nas quais experimentamos o prazer físico.

Os prazeres maiores são, de acordo com esse mesmo autor, muito parecidos com os prazeres físicos no que tange às sensações positivas que proporcionam e à sua brevidade. Porém são muito mais complexos em relação ao modo como se instalam, sendo também mais cognitivos, numerosos e variados do que os prazeres 
físicos. Os prazeres maiores podem, ainda, ser classificados de acordo com sua intensidade, conforme podemos visualizar na seguinte tabela:

\section{Tabela 1: Classificação dos prazeres maiores}

\begin{tabular}{|c|c|c|}
\hline \multicolumn{3}{|c|}{ P R A Z E R E S M A I O R E S } \\
\hline Alta Intensidade & Intensidade Moderada & Baixa Intensidade \\
\hline $\begin{array}{c}\text { Enlevo, deleite, êxtase, } \\
\text { hilaridade, euforia, } \\
\text { empolgação, sublimidade, } \\
\text { júbilo e excitação. }\end{array}$ & $\begin{array}{c}\text { Animação, encantamento, } \\
\text { vigor, regozijo, contentamento, } \\
\text { alegria, bom-humor, } \\
\text { entusiasmo, atração e graça. }\end{array}$ & $\begin{array}{c}\text { Conforto, harmonia, } \\
\text { divertimento, saciedade e } \\
\text { relaxamento. }\end{array}$ \\
\hline Fonte: Seligman (2004)
\end{tabular}

De acordo com a Psicologia Positiva é possível aumentarmos a quantidade de prazer em nossas vidas, desde que consideremos três aspectos aos quais todos prazeres se encontram submetidos: habituação, apreciação e atenção.

A habituação corresponde à adaptação que ocorre ao nível cerebral, em relação à repetição de um mesmo prazer. É ela que faz com que um mesmo prazer, repetido com freqüência, perca seu efeito. Ávida por obter o mesmo prazer anterior, a pessoa repete a mesma atividade por inúmeras vezes. Essa insistência provoca a habituação que, por sua vez, diminui ainda mais a possibilidade da obtenção do prazer, fechando um ciclo vicioso. É exatamente nesse aspecto que reside o potencial negativo do prazer, ou seja, sua capacidade de gerar dependência. É por isso que Seligman (2004) propõe que os eventos geradores de prazer sejam intercalados com outros tipos de eventos, de forma a proporcionar um espaçamento de tempo mais adequado e capaz de manter a habituação dos prazeres sob controle. 
Para Bryant (1989) a apreciação consiste na consciência e apreciação deliberada em relação à experiência de prazer. Sendo assim, são quatro os tipos de apreciação: satisfação (em virtude do recebimento de elogios e congratulações), agradecimento (resultado da expressão de gratidão pelo que foi recebido), admiração (resultante da percepção da maravilha de um determinado momento) e o conforto (conseqüência do prazer dos sentidos) (Idem, 2004).

Finalmente, temos a atenção como sendo o terceiro aspecto a ser considerado quando se pretende aumentar os momentos de prazer. O ritmo da vida moderna não parece favorecer o direcionamento da atenção para as atividades que provocam o prazer. Ameaçados pela velocidade da informação, encontramo-nos hoje, mais do que nunca, atolados por crescentes exigências pessoais, profissionais e sociais. São muitos os apelos que disputam a atenção do homem contemporâneo e, talvez em nenhum outro momento da história, eles tenham se apresentado de forma tão dinâmica. O avanço tecnológico, bem como os altos índices de desemprego mundial apontam para uma necessidade de qualificação e aperfeiçoamento profissionais constantes, o que deixa pouco tempo para que possamos direcionar nossa atenção para atividades que nos trazem prazer. O sociólogo italiano Domenico De Masi (1999) é enfático ao afirmar que, ao construir sua vida em torno do trabalho, o homem perdeu, a partir da Revolução Industrial, sua habilidade para o ócio e para o lazer - ao que acrescentaríamos - ao prazer. Este autor afirma ainda a possibilidade de que o ócio venha a se tornar, na sociedade pós-industrial, tão importante quanto o trabalho, na medida em que, como conseqüência do próprio desenvolvimento tecnológico, a oferta de emprego tem se tornado cada vez menor. 
Enquanto isso não ocorre, ainda experimentamos um certo sentimento de culpa ao focarmos nossa disputada atenção para atividades tão "inúteis" quanto aquelas que, simplesmente, nos trazem prazer. Contudo esse é um dos caminhos que levam à uma vida prazerosa, ou seja, é preciso que se focalize a atenção na atividade prazerosa a fim de que seja possível beneficiar-se do prazer que ela provoca.

Nesse sentido, devemos considerar também que a atenção é fortemente influenciada pelos estados de humor (Hewitt, 2002), tendendo a ocorrer com muito mais facilidade quando acompanhada por um estado de espírito de tranqüilidade, do que em meio a pressões e preocupações com o futuro (Seligman, 2004).

\section{A Gratificação}

De acordo com Csikszentmihalyi (1992), o sentimento de gratificação ocorre não simplesmente em função da realização de um desejo ou suprimento de uma necessidade, como ocorre com o prazer, mas sim quando a pessoa ultrapassa aquilo que foi programada a fazer, alcançando algo inesperado que, talvez, sequer havia imaginado. A gratificação caracteriza-se por impulsionar o indivíduo para a frente no sentido de seu auto-desenvolvimento, provocando uma sensação de novidade e realização.

Após um acontecimento que causa gratificação, sabemos que mudamos, que nosso self expandiu-se: tornamo-nos mais complexos em alguns aspectos, como conseqüência dele.

(Csikszentmihalyi, 1992, p.75) 
Para Seligman (2004) a gratificação, ao contrário do prazer, não mantém relação com o prazer físico nem se trata de um estado que pode ser quimicamente induzido ou alcançado através de alguma manobra. Para este autor, enquanto o prazer pode ser, conforme já vimos, descoberto, alimentado e ampliado, o mesmo não ocorre em relação à gratificação. Enquanto os prazeres estão ligados aos sentidos e às emoções, as gratificações estão ligadas ao exercício das forças e virtudes pessoais (Idem, 2004). Considerando sua relevância para a compreensão da gratificação - e por extensão, da própria felicidade - discutiremos melhor essas forças e virtudes no item 1.2. Por hora, é suficiente que se compreenda que as situações que levam à gratificação exigem um investimento cognitivo que, quando em sintonia com as capacidades do indivíduo, criam uma situação favorável para que ele se deixe absorver completamente.

É importante salientar também, que a gratificação não se encontra no tipo de atividade que se exerce, mas na forma como a mesma é exercida. Para Csikszentmihaly (1992) as mesmas experiências que nos dão prazer são capazes de proporcionar gratificação. Comer uma refeição bem feita costuma dar prazer para a maioria das pessoas, sobretudo quando se está com fome. No entanto, são poucos os que conseguem, efetivamente, apreciar a comida. Para um gourmet, assim como para qualquer outro que seja capaz de diferenciar as diversas sensações provocadas por uma refeição, é possível obter gratificação através do ato de comer (Idem, 1992). O filme dinamarquês A Festa de Babette, dirigido por Gabriel Axel, diferencia muito bem o prazer e a gratificação que podemos obter através da comida. 
O que fica evidente no caso da gratificação é sua maior complexidade em relação ao prazer, visto sua exigência de investimento psíquico na conquista de metas novas e desafiadoras.

Talvez a melhor forma de compreendermos a gratificação, seja através do conceito de flow, desenvolvido pelo psicólogo de ascendência húngara Mihaly Csikszentmihalyi em Csikszentmihalyi $(1992,1999)$ e em Nakamura e Csikszentmihalyi, (2002). No entanto, para compreendermos o flow devemos recorrer a dois outros conceitos: consciência e self, que juntos, referem-se a um modelo desenvolvido paralelamente ao conceito de flow e que se propõe a descrever a experiência humana em termos mais gerais (Csikszentmihaly \& Csikszentmihaly, 1988 apud Nakamura \& Csikszentmihaly, 2002).

\section{A consciência}

A consciência funciona como uma espécie de central informativa que processa sensações, percepções, sentimentos e idéias, estabelecendo prioridade entre eles a fim de representar a informação sobre o que acontece dentro e fora do organismo, de modo que isso possa ser avaliado pelo corpo, fazendo-o agir de acordo (Csikszentmihalyi, 1992). Seguindo uma tendência de compreensão da mente como um sistema de representação computacional, Johnson-Laird (1983) compara a consciência a um tipo de sistema operacional do cérebro, que, tal como fazem as plataformas Windows, DOS ou Macintosh, desempenham o papel de mudar as fontes de processamento, baseadas em quais tarefas têm maior prioridade. 
A partir dessa metáfora, a consciência desempenharia o mesmo papel em relação aos conteúdos da mente, priorizando conteúdos de particular importância sensorial e emocional.

No entanto, a analogia entre consciência e sistemas operacionais de computador deixa a desejar, na medida em que o cérebro é muito mais complexo do que o computador em relação ao processamento simultâneo de informações. (Thagard, 1998). Além disso, a metáfora do sistema operacional sugere que a consciência desempenha um papel de processadora central quando, na verdade, sabemos que ela pode estar ligada a processos de interpretação descentralizados, paralelos e com muitas possibilidades (Dennett, 1991).

Desde a década de 50, a ciência cognitiva, definida como sendo o estudo interdisciplinar da mente e da inteligência (Thagard, 1998), vem se utilizando de representações complexas e procedimentos na área de computação. Ainda hoje, mesmo com o desenvolvimento das chamadas neurociências, a teoria computacional é indispensável para a compreensão da evolução da mente, na medida em que, mais do que na estrutura do cérebro, o conteúdo da atividade cerebral reside nos padrões de conexões e nos padrões de atividade entre os neurônios (Pinker, 1998) ou seja, na forma como a informação entre eles é processada.

Isso não implica na aceitação da ultrapassada "metáfora do computador" para a compreensão da mente humana (Idem, 1998), visto que: 
... os computadores são seriais, fazendo uma coisa por vez; os cérebros são paralelos, fazendo milhões de coisas de uma vez. Computadores são rápidos; cérebros são lentos. As partes de computadores são confiáveis; as partes do cérebro apresentam ruído. Os computadores apresentam um número limitado de conexões; os cérebros possuem trilhões. Os computadores são montados segundo um projeto; os cérebros têm de montar-se sozinhos".

(Ibidem, 1998, p. 37)

Para a Psicologia Positiva, no entanto, a melhor forma de analisar e compreender o funcionamento da mente é através do chamado "modelo fenomenológico da consciência”, baseado na teoria da informação (Csikszentmihalyi, 1992). Trata-se de uma representação fenomenológica da consciência, uma vez que lida diretamente com os acontecimentos - fenômenos - conforme os interpretamos e não com as estruturas cerebrais, processos neuroquímicos ou aspectos inconscientes que tornam possíveis esses acontecimentos (Idem, 1992). Contudo, ao contrário da fenomenologia pura que, intencionalmente, exclui de seu método qualquer outra teoria ou ciência, o modelo mencionado emprega princípios da teoria da informação considerados relevantes para a compreensão do que acontece na consciência. Esses princípios incluem o conhecimento de como os dados sensoriais são processados, armazenados e utilizados, o que, mais especificamente, corresponde à compreensão acerca da dinâmica da atenção e da memória (Ibidem, 1992). 
Em linhas gerais, podemos dizer que a consciência é um sistema complexo que evolui no ser humano através da seleção, processamento e armazenamento de informações (Nakamura \& Csikszentmihalyi, 2002). Embora seja, inegavelmente, resultado de processos biológicos, a consciência desenvolveu a capacidade de ultrapassar suas instruções genéticas e estabelecer seu próprio curso de ação independente (Csikszentmihalyi, 1992), o que determina, na visão da Psicologia Positiva, uma de suas características principais: a autodeterminação.

Podemos dizer que boa parte dessa autodeterminação é conseqüência da atenção. Enquanto tudo o que sentimos, cheiramos, ouvimos ou lembramos é potencialmente capaz de penetrar na consciência, as experiências que, de fato, acabam se tornando parte dela, são em número bem menor do que as que são deixadas do lado de fora (Csikszentmihalyi, 1992). Em outras palavras, a informação aparece na consciência através do investimento seletivo de atenção (Nakamura \& Csikszentmihalyi, 2002). Uma vez prestada a atenção, a informação entra na consciência num sistema que inclui todos os processos que dela fazem parte, tais como cognição, motivação e emoção, para mais tarde ser armazenada e recuperada pela memória (Idem, 2002).

No entanto, considerando que o sistema nervoso possui um limite definido para a quantidade de informação que é capaz de processar a cada momento, o que determinará a organização da consciência são as diferentes metas e intenções de cada indivíduo. Isso significa que a informação que deixamos penetrar na consciência torna-se muito importante, na medida em que ela é, em última instância, o que determinará o conteúdo e a qualidade de vida (Csikszentmihalyi, 1992). 


\section{O conceito de self para a Psicologia Positiva}

Em linhas gerais, o self corresponde ao que costumamos chamar de eu. Tratase de um dos conteúdos da consciência que nunca se distancia muito do foco da atenção. Todavia, o self não é um elemento de informação como qualquer outro. $\mathrm{Na}$ verdade, ele contém tudo o que passou pela consciência: todas as lembranças, ações, desejos, prazeres e dores estão nele incluídos (Csikszentmihalyi, 1992). Além disso, o self representa a hierarquia de metas que construímos ao longo dos anos (Idem, 1992).

De acordo com Nakamura \& Csikszentmihalyi (2002) a Psicologia Positiva acredita que o self possui um duplo aspecto:

a-) A soma dos processos conscientes do indivíduo;

b-) A informação sobre si mesmo que entra na consciência quando o indivíduo torna-se objeto de sua própria atenção.

Ao se tornar consciente de si mesmo quanto às informações sobre o próprio corpo, estados subjetivos, memórias e futuro pessoal, o indivíduo constrói seu self. Isso significa, em outras palavras, que o self surge através da consciência (Nakamura \& Csikszentmihalyi, 2002). A partir daí, toda a informação inserida na consciência -e portanto, toda a informação para a qual se voltou a atenção - fará parte do self. No entanto, o interessante é que será o próprio self quem fará a triagem entre as milhares de informações disponíveis no ambiente - escolhendo aquelas que efetivamente farão parte da consciência. É de se esperar, por exemplo, que um escritor, ao ler um texto qualquer, registre muito mais informações acerca de aspectos como construção frasal, estilística e sonoridade do que qualquer outro leitor interessado simplesmente no conteúdo a ser transmitido. 
Da mesma forma, um somelier conseguirá perceber aspectos de um vinho que passarão despercebidos para a grande maioria das pessoas. O caráter curioso desses exemplos é que o fato de se tratar de um somelier fará com que o self desse indivíduo focalize sua atenção para determinados aspectos do vinho, ao mesmo tempo em que é justamente sua capacidade de perceber esses aspectos que faz desse indivíduo um somelier, o mesmo acontecendo em relação ao escritor e ao texto por ele lido. Isso significa que o self, ao mesmo tempo em que determina a atenção, também é determinado por ela (Csikszentmihalyi, 1992). Além disso, dizemos também que o self se organiza em função de objetivos (Snyder, Rand \& Sigmon, 2002; Locke, 2002), visto que, tanto para a triagem das informações quanto para sua organização dentro da consciência, ele deverá estabelecer uma prioridade em relação às metas do indivíduo.

Se, de alguma forma, a informação entrar em conflito ou ameaçar as metas pessoais, teremos uma desorganização do self, chamada "entropia psíquica" que prejudicará sua eficiência (Csikszentmihalyi, 1992). No entanto, o contrário também é verdadeiro. Para a Psicologia Positiva a felicidade e a qualidade de vida estão intimamente relacionadas com a capacidade de controlar a consciência, visto que, desta última, depende o próprio self, ou como explica Csikszentmihalyi: 
Vimos que a experiência depende do modo como investimos a energia psíquica - na estrutura da atenção. Esta, por sua vez, relaciona-se com metas e intenções. Estes processos estão ligados um ao outro pelo self, ou seja, pela representação mental dinâmica que temos do sistema total de nossas metas. São essas peças que devem ser movidas se desejamos melhorar as coisas.

(1992, p.61)

Isto não significa que a Psicologia Positiva negue a influência de eventos externos na qualidade de vida das pessoas, visto que, mesmo acontecimentos maravilhosos, como ganhar na loteria, precisam assumir seu lugar na consciência, associando-se de modo positivo com o self, antes que possam influenciar na qualidade de vida (Ibidem, 1992).

\section{O Conceito de Flow ${ }^{3}$}

O conceito de flow foi desenvolvido na década de 60 pelo psicólogo Mihaly Csikszentmihalyi que, a partir do estudo do processo criativo, interessou-se pelo fenômeno da motivação intrínseca ou pela chamada atividade autotélica ${ }^{4}$ (Nakamura \& Csikszentmihaly, 2002).

Em linhas gerais, podemos dizer que o flow se caracteriza por um estado de concentração total na atividade que está sendo realizada, capaz de fazer com que o indivíduo perca a noção da realidade.

\footnotetext{
${ }^{3}$ Embora alguns tradutores traduzam flow por fluir, outros preferem manter o termo em Inglês. Concordando com essa segunda tendência, achamos mais adequada a utilização do termo original.

${ }^{4}$ Atividade recompensadora por si mesma, independentemente de seu produto final ou qualquer bem extrínseco que dela possa resultar.
} 
Para Csikszentmihalyi (1992) o flow, também chamado de experiência máxima, é o oposto da já mencionada entropia psíquica, daí também ser conhecido como negantropia. Em outras palavras, a experiência máxima corresponde:

... a situações nas quais a atenção pode ser livremente investida para alcançar as metas pessoais, porque não existe desordem a ser corrigida, nem ameaça contra a qual o self precise defender-se. Chamamos este estado de experiência do fluir, porque é um termo usado por muitas pessoas que entrevistamos para descrever como se sentem, quando em sua melhor forma...

(Idem, 1992. p. 67)

De acordo com Nakamura \& Csikszentmihalyi (2002), as condições para que o flow aconteça, incluem:

- Desafios percebidos ou oportunidades para a ação que exigem (nem a mais nem a menos) das habilidades existentes; uma sensação de que se está engajado num desafio cujo nível é adequado ao tamanho das próprias capacidades

- Uma atividade com objetivos claros e feedback imediato em relação ao progresso que nela se está sendo feito.

Mantidas tais condições, o indivíduo poderá entrar no chamado estado de flow; estado este que, de acordo com esses mesmos autores, apresentará as seguintes características: 
- Concentração intensa e focada: Voltada para aquilo que se está fazendo no momento presente

- Fusão entre ação e consciência: Esta fusão provocará uma espécie de bloqueio da consciência, na medida em que a atenção estará focada apenas para a ação

- Perda da auto-consciência reflexiva: Perda da consciência de si mesmo como ator social

- Sensação de controle sobre as próprias ações: Sensação de que, em princípio, se é capaz de lidar com a situação, por saber exatamente como responder aos acontecimentos

- Distorção da experiência temporal: Normalmente uma sensação de que o tempo passou mais rápido do que o normal

- Experiência de que a atividade é intrinsecamente recompensadora: De forma que o objetivo final é apenas uma desculpa para o processo.

Partindo dessas características, Seligman (2004) afirma que "o que está no coração do flow é a ausência de emoção, de qualquer tipo de consciência" (p. 137).

Mas talvez seja na sua relação com a complexidade do self que reside a característica mais importante do flow, na medida em que "depois de ter se sentido fluir, a organização do self torna-se mais complexa do que antes. É ao tornar-se progressivamente mais complexo que o self cresce" (Csikszentmihalyi, 1992. p.68). Tal complexidade é resultado de dois processos psicológicos descritos por Csikszentmihalyi (1992): a diferenciação e a integração. 
A diferenciação corresponde a um movimento em direção à individualidade, ou seja, da capacidade de diferenciar o si mesmo das outras pessoas. Para esse mesmo autor, a experiência de flow torna o self mais diferenciado, na medida em que a superação de um desafio faz, inevitavelmente, com que o indivíduo se sinta mais apto e capaz, tornando-se mais singular, menos previsível e dotado de capacidades mais raras.

A integração, por sua vez, trata-se do oposto, correspondendo à união do self com outras pessoas, idéias e seres exteriores a ele. Para Csikszentmihalyi (1992), o flow ajuda também a integrar o self na medida em que o estado de profunda concentração indica que a consciência está extraordinariamente organizada. Se, conforme já dissemos, a consciência corresponde à realidade vivenciada de forma subjetiva, seu conteúdo inclui não apenas o self, mas também todo o tipo de informações relativas à pessoas, idéias e acontecimentos exteriores a ele. Dizer que os conteúdos da consciência estão organizados é o mesmo que dizer que não há conflito entre eles, ou seja, que o self e as demais informações da consciência estão em harmonia o que, em última instância, significa estarem integrados.

Por essa razão, um self apenas diferenciado - mas não integrado - costuma ser capaz de alcançar grandes realizações individuais, porém, sob o risco de perder-se no egocentrismo e no auto-centramento (Idem, 1992). Seguindo essa mesma linha, uma pessoa cujo self se baseia exclusivamente na integração será solidária e segura, porém não terá muita individualidade nem autonomia (Ibidem, 1992).

Podemos dizer que a Psicologia Positiva acredita na complexidade do self como sendo uma peça-chave para a conquista de uma vida feliz (Seligman, 2004), daí a importância que dá à experiência de flow. 
A forma de atingir essa complexidade é descrita por Csikszentmihalyi:

Somente quando uma pessoa investe quantidades iguais de energia psíquica nesses dois processos [diferenciação e integração] e evita tanto o egoísmo como o conformismo é que seu self poderá exprimir complexidade.

Podemos dizer então que a teleonomia ${ }^{5}$ do self seja um princípio de crescimento; o nível ótimo de desafio que exige das habilidades existentes (Vygotsky, 1978), resultando em um conjunto mais complexo de capacidades para a ação. Este aspecto diferencia o modelo de flow das teorias que definem o desafio ótimo em termos tanto de um ponto de equilíbrio homeostático para o qual se deva retornar quanto das que o vêem como um nível máximo de desafio a ser vencido (Moneta \& Csikszentmihalyi, 1996). Isso ocorre porque a experiência de flow não apenas fornece um conjunto de desafios e oportunidades para a ação mas também, tipicamente, oferece um sistema de desafios graduais que leva o indivíduo a envolver-se com a atividade, contínua e profundamente, promovendo a gratificação e o aumento de suas habilidades (Nakamura \& Csikszentmihalyi, 2002).

Conforme já dissemos, o flow ocupa um papel de destaque dentro da Psicologia Positiva devido à estreita relação que mantém com a felicidade.

\footnotetext{
${ }^{5}$ Doutrina segundo a qual a existência de uma estrutura ou função orgânica se deve às vantagens seletivas por elas proporcionadas.
} 
Contudo, a relação entre flow e felicidade não é, de acordo com Csikszentmihalyi (1999) inteiramente auto-evidente. Isto porque durante a experiência de flow a pessoa está tão entretida na tarefa que, perceber-se feliz, seria uma distração e, portanto, uma interrupção do flow (Idem, 1999).

De qualquer forma, pesquisas apontam que garotos que relataram ter experienciado altos índices de flow, chegam à universidade, desenvolvem laços sociais mais profundos e são mais bem-sucedidos do que seus pares com um índice menor desse tipo de experiência (Seligman, 2004).

Embora a capacidade para o flow seja universal, existe uma grande variabilidade na freqüência do flow relatado, bem como na qualidade da experiência e no desejo de permanecer fazendo a atividade quando as capacidades e desafios são simultaneamente altos; o que sugere que esse equilíbrio, embora importante, não seja suficiente para a ocorrência do flow (Nakamura \& Csikszentmihalyi, 2002).

Por depender de que as habilidades do indivíduo sejam trabalhadas, o flow não acontece durante o exercício de atividades que oferecem poucos desafios, ainda que o indivíduo perceba um equilíbrio entre tais desafios e suas habilidades (Nakamura e Csikszentmihalyi, 2002).

Como se vê, o fato de estar absorvido numa tarefa não é garantia de flow, embora assim se tenha pensado inicialmente. Nos dias de hoje muitos adolescentes passam horas diante do computador e, nem por isso tornam-se mais felizes, o que seria de esperar caso tal atividade estivesse, de fato, promovendo a complexidade do self. 
Com o objetivo de compreender melhor o impacto social e psicológico da Internet na vida das pessoas, um grupo de pesquisadores da Carnegie Mellon University (Kraut, R. et all, 1998) realizou um estudo longitudinal com 169 pessoas em 73 famílias durante seus dois primeiros anos on-line. Os resultados indicaram que, a despeito de um proeminente uso da Internet para fins de comunicação, um grande uso da internet estava, na amostra estudada, associado: ao declínio na comunicação dos sujeitos com os demais membros da família, à redução do círculo social e ao aumento da depressão e solidão.

Resultados como este, fizeram com que o conceito de flow fosse redefinido como sendo um estado que se caracteriza pelo "equilíbrio entre desafios e habilidades, quando ambos se encontram acima dos níveis médios do indivíduo" (Nakamura \& Csicszentmihalyi, 2002, p. 95)

Tanto a teoria quanto a pesquisa sobre o flow têm se focado muito mais na fenomenologia do que na personalidade daqueles que o experienciam (Nakamura \& Csikszentmihalyi, 2002). Tal tendência se justifica através do objetivo prioritário de compreender a dinâmica da experiência momentânea e as condições sob as quais ela se torna ótima (Idem, 2002). Todavia, desde o início de suas pesquisas, Csikszentmihalyi reconheceu a possibilidade do que chamou de "personalidade autotélica" que corresponderia ao indivíduo com tendência a aproveitar a vida e fazer as coisas por si mesmas e não visando qualquer tipo de objetivo externo futuro (Nakamura \& Csikszentmihalyi, 2002). Segundo esse autor, a personalidade autotélica inclui determinadas competências que tornam o sujeito capaz de entrar e permanecer em flow, tais como: curiosidade geral pela vida, persistência e baixo autocentramento. 
Este último se justifica devido ao fato de tornar possível a motivação intrínseca. Quando, ao contrário, ocorre a motivação extrínseca, a atenção se volta para o self e suas deficiências, criando uma auto-consciência que impede o enfrentamento de desafios (Csikszentmihalyi, 1992).

Conforme pudemos observar, os caminhos que levam ao prazer e à gratificação são muito diferentes e, principalmente conduzem a destinos próximos entre si, porém distintos. Movidos pelo apelo da sociedade moderna, freqüentemente acabamos por "tomar a via errada", cometendo o equívoco de julgar que o destino almejado não existe. Por essa razão acreditamos que qualquer tentativa de contribuir para a promoção da felicidade humana deva começar através da diferenciação entre prazer e gratificação. Nesse sentido, a tabela 2 oferece uma síntese das principais diferenças entre esses dois estados:

Tabela 2 - Comparação entre Prazer e Gratificação

\begin{tabular}{|c|c|c|}
\hline CARACTERISTICA & PRAZER & GRATIFICAÇÃO \\
\hline Exigência cognitiva & Baixa ou nenhuma & Alta \\
\hline Componentes Sensoriais & Muitos & Poucos ou nenhum \\
\hline Componentes Emocionais & Muitos & Nenhum \\
\hline Utilização de Forças e Virtudes & Não & Sim \\
\hline Duração & Efêmera & Longa \\
\hline Crescimento do Self & Não & Sim \\
\hline Potencial de "Adicção" & Alto & Baixo \\
\hline RESULTADo & Vida Prazeirosa & Vida Feliz \\
\hline
\end{tabular}

Fonte: Seligman (2004) 
Sabemos, no entanto, que, embora importante, a diferenciação entre esses dois conceitos não é suficiente para trazer felicidade à vida humana. E, nesse sentido, o aumento dos momentos de gratificação - via experiências de flow - parecem ser mais promissores, por criarem, como vimos, uma exigência em relação às habilidades do indivíduo, acrescentando complexidade ao seu self.

Essas habilidades correspondem às chamadas forças pessoais, que serão melhor discutidas no capítulo seguinte. 


\subsection{Virtude, Caráter e \\ Forcas Pessoais}

De acordo com Seligman (2004) a principal suposição da Psicologia Positiva é a idéia do bom caráter. Em seu dicionário de Psicologia, Corsini (2002, p.155) define caráter como sendo:

"A totalidade de qualidades ou traços, particularmente no tocante a características morais, sociais e atitudes religiosas de uma pessoa. Chamamos de caráter àquilo que uma pessoa, de fato, é, e de personalidade, àquilo que ela parece ser".

[Tradução livre]

Deixado de lado pela Psicologia, o caráter, assim como a virtude e a própria felicidade humana, acabaram sendo apropriados por outras áreas do conhecimento que variavam do senso comum ao pensamento religioso. Contudo, nem sempre foi assim. De acordo com Seligman (2004), a noção de bom caráter era comum no século XIX, pois, nessa época, boa parte da insanidade era vista como defeito e degeneração moral, de forma que a explicação contemporânea de que a causa do mau comportamento tem suas raízes nas condições de vida desfavoráveis, era completamente estranha ao pensamento da época.

Nesse sentido, Seligmam (2004) aponta o surgimento, já no início do século XX, das Ciências Sociais como representante de uma nova agenda científica nas grandes universidades americanas, "cujo objetivo era explicar o comportamento (e o mau comportamento) dos indivíduos como resultado não de seu caráter, mas de poderosas e tóxicas forças ambientais que fugiam a seu controle"(p. 147). 
A ênfase nessa forma de explicar o comportamento humano a qual podemos chamar de ambientalismo, deu origem à idéia de que o ser humano, ao nascer, seria como uma "tabula rasa" sobre a qual seriam escritos os contornos de sua personalidade, estes determinados por sua interação com o ambiente. De acordo com Pinker (2004), a doutrina da "tabula rasa", cujo mal maior foi a negação da natureza humana, norteou, durante todo o século $X X$, a maioria dos trabalhos nas chamadas ciências humanas, servindo de base para o desenvolvimento de crenças políticas e éticas.

É importante ressaltar que a reação contra as explicações do comportamento baseadas no caráter, encontraram importantes respaldos nos pensamentos de Marx, Freud e Darwin (Seligman, 2004). De acordo com o pensamento marxista, os trabalhadores não podiam ser responsabilizados e acusados individualmente pelas greves, ações ilegais e tumultos que acompanhavam as ações operárias, uma vez que esses nada mais eram do que conseqüência da dissociação entre trabalho e mãode-obra, ou da chamada luta de classes (Idem, 2004). A partir de sua idéia de inconsciente, Freud dizia que indivíduos emocionalmente perturbados não poderiam ser responsabilizados por seus atos destrutivos, na medida em estes eram causados por forças incontroláveis de seus conflitos inconscientes (Ibidem, 2004). Seligman (2004) nos lembra ainda que "Darwin é visto por alguns como justificativa para não acusar indivíduos pela cobiça e pelos males da competição desenfreada, já que eles estão simplesmente à mercê da inevitável força da seleção natural"(p. 147). Como vimos, a ênfase no ambiente foi, aos poucos, enfraquecendo a idéia (ou a importância) do caráter, visto que, em última instância, este seria passível de 
sucumbir diante das forças de um meio ambiente nocivo.

De acordo com Pinker (2004, p. 13), “a negação da natureza humana transbordou da academia e provocou uma desconexão entre a vida intelectual e o bom senso". O único setor da Psicologia científica que manteve acesa a chama do caráter e da idéia da natureza humana, por todo o século $X X$, foi o estudo da personalidade. Não obstante isso, o termo caráter, devido à sua conotação prescritiva, foi sendo substituído por personalidade, termo este de natureza mais descritiva, exatamente como os termos científicos devem ser (Seligman, 2004).

De acordo com Peterson \& Seligman (2004), foram três as razões pelas quais a Psicologia deixou de lado a idéia do caráter: A primeira delas advém da crença de que o caráter, enquanto fenômeno, seria totalmente derivado da experiência. Descobertas recentes sobre a condição de herança da personalidade (leia-se caráter) comprovam que "qualquer constituição do caráter não resulta apenas do ambiente, se é que o ambiente exerce alguma influência"(p. 149). A segunda razão seria a de que, por ter uma conotação prescritiva, o termo caráter não estaria em conformidade com o pensamento científico que, por sua vez, deve ser moralmente neutro. Seligman (2004) rebate essa idéia dizendo que a Psicologia Positiva não tem a função de recomendar às pessoas que sejam otimistas, bondosas, espirituais ou bem-humoradas, mas sim a de descrever as conseqüências dessas características para que cada um, de acordo com seus valores e objetivos, possa optar por desenvolver em si mesmo tais qualidades. Ainda de acordo com Seligman (2004), a terceira razão que justificaria o abandono do caráter como objeto de estudo da Psicologia, seria o fato de o mesmo ser carregado de valor e estar ligado ao protestantismo vitoriano. 
Nesse sentido, Peterson \& Seligman (2004) defendem a posição da Psicologia Positiva dizendo que entre a decisão de estudar apenas as virtudes valorizadas pelos protestantes norte-americanos do século XIX ou pelos brancos, acadêmicos, de meiaidade, do sexo masculino, do século $X X$, essa nova abordagem optou por começar pelo estudo das forças e virtudes valorizadas praticamente em todas as culturas.

Partindo da análise dos textos básicos de todas as religiões e tradições filosóficas orientais e ocidentais, os estudiosos da Psicologia Positiva analisaram a idéia de virtude em cada uma delas, procurando por eventuais constâncias entre as mesmas, conforme relata Seligman (2004, p 153):

“... lemos Aristóteles e Platão, Santo Tomás de Aquino e Santo Agostinho, O Velho Testamento e o Talmude, Confúcio, Buda, Lao Tze, o Bushido (o código samurai), o Alcorão, Benjamin Franklin e os Upanishads - uns 200 catálogos de virtudes ao todo. Para nossa surpresa, quase todas essas tradições, que atravessaram 3.000 anos e toda a face da Terra, endossavam seis virtudes: sabedoria, coragem, humanidade, justiça, temperança e transcendência".

De acordo com Peterson e Seligman (2004), chamamos de virtudes às principais características humanas valorizadas por filósofos da moral e pensadores religiosos e cujo desenvolvimento biológico se deu através de um processo evolutivo que selecionou tais aspectos de excelência como meio para a resolução de importantes tarefas necessárias à sobrevivência da espécie.

Dessa forma, uma pessoa virtuosa seria aquela que, por vontade própria, demonstrasse todas, ou pelo menos a maior parte dessas seis virtudes. 
Existem, contudo, vários caminhos distintos que conduzem a tais virtudes, caminhos estes que são chamados de forças de caráter ou simplesmente, forças pessoais (Seligman, 2004; Peterson \& Seligman, 2004). "A virtude da justiça, por exemplo, pode ser demonstrada por meio de atos de cidadania, imparcialidade, lealdade, liderança e espírito de equipe; a esses caminhos chamo de forças e, ao contrário das virtudes abstratas, cada uma delas é mensurável e passível de ser adquirida" (Seligman, 2004).

De acordo com Peterson \& Seligman (2004), para ser classificada como força de caráter, uma característica positiva deve satisfazer a maioria dos seguintes dez critérios:

1- Uma força contribui para a satisfação gerada por uma vida boa tanto para si mesmo quanto para os outros.

2- Uma força vale por si, ou seja, sua valorização moral independe dos resultados benéficos que produz.

3- $\quad$ A demonstração de uma força por uma pessoa não diminui em nada aqueles com quem convive, chegando mesmo a inspirá-los.

4- Uma pessoa ser capaz de exprimir o oposto de uma força putativa em determinada situação, depõe contra considerar que, de fato, tal força se trate de uma força de caráter.

5- $\quad$ Uma força deve ser um traço, ou seja, uma característica psicológica que pode ser observada em várias situações diferentes, demonstrando estabilidade em relação ao tempo.

6- $\quad$ A força é diferente de outras características positivas na classificação e não pode ser decomposta dentro delas. 
7- Uma força de caráter é edificada sobre padrões consensuais.

8- $\quad$ Algumas forças têm prodígios, ou seja, jovens que as demonstram cedo e incrivelmente bem.

9- $\quad$ Por outro lado, existem pessoas que demonstram, seletivamente, uma total ausência de uma dada força.

10- A sociedade proporciona instituições e rituais associados ao cultivo de forças e virtudes para, assim, sustentar sua prática.

Utilizando-se do critério da ubiqüidade, a Psicologia Positiva chegou a vinte e quatro forças de caráter, valorizadas em praticamente todas as culturas do mundo, o que permite que se chegue à formulação de uma vida boa que se aplique a pessoas das mais diversas nacionalidades (Seligman, 2004).

Vale ressaltar que um dos primeiros obstáculos encontrados pela Psicologia Positiva em seu objetivo de promover o bom caráter, foi justamente a ausência de uma nomenclatura precisa nessa área. Assim como ocorrera com as doenças mentais cuja não-confiabilidade de diagnósticos deu origem ao DSM (Manual de Estatística e Diagnóstico das Doenças Mentais), foi necessária a criação de uma classificação de sanidades que funcionasse como espinha dorsal da Psicologia Positiva e que deu origem a um manual que serviu de base a este capítulo.

No entanto, de acordo com Maddux (2002) há ainda um grande desafio a ser vencido, representado por uma nova ideologia que, segundo ele, deve começar através de uma mudança na linguagem que usamos para falar sobre 0 comportamento humano e os problemas que os seres humanos enfrentam durante 0 curso de suas vidas - uma mudança de uma linguagem pautada na ideologia da 
doença para uma linguagem pautada na Psicologia Positiva.

A partir de seus estudos, a Psicologia Positiva chegou a vinte e quatro forças pessoais, cada uma delas ligada a uma das seis virtudes já mencionadas, conforme podemos melhor visualizar na tabela 3 :

Tabela 3 - As Forças Pessoais e suas relações com as Virtudes

\begin{tabular}{|c|c|}
\hline VIRTUDES & "FORÇAS DE CARÁTER \\
\hline \multirow{5}{*}{$\begin{array}{c}\text { Sabedoria e } \\
\text { Conhecimento }\end{array}$} & Criatividade \\
\hline & Curiosidade \\
\hline & Lucidez \\
\hline & Gosto pela Aprendizagem \\
\hline & Perspectiva (sabedoria) \\
\hline \multirow{4}{*}{ Coragem } & Bravura \\
\hline & Persistência \\
\hline & Integridade \\
\hline & Vitalidade \\
\hline \multirow[b]{3}{*}{ Humanidade } & Amor \\
\hline & Bondade \\
\hline & Inteligência Social \\
\hline \multirow[b]{3}{*}{ Justiça } & Cidadania \\
\hline & Imparcialidade \\
\hline & Liderança \\
\hline \multirow{4}{*}{ Temperança } & Perdão e misericórdia \\
\hline & Humildade/ modéstia \\
\hline & Prudência \\
\hline & Auto-regulação (auto-controle) \\
\hline \multirow{5}{*}{ Transcendência } & Apreciação da beleza e excelência \\
\hline & Gratidão \\
\hline & Esperança \\
\hline & Humor \\
\hline & Espiritualidade \\
\hline
\end{tabular}

Fonte: Peterson \& Seligman (2004). 


\section{Locus de Controle}

Embora não neguemos a influência dos eventos externos nos níveis de felicidade do indivíduo, concordamos com Lyubomirsky (2001) que, ao estudar a felicidade humana, destaca a importância dos múltiplos processos cognitivos e motivacionais que moderam o impacto que o ambiente externo é capaz de exercer no bem-estar subjetivo. Assim como Csikszentmihalyi (1999) partimos da premissa de que, sendo a felicidade um estado mental, as pessoas deveriam ser capazes de controlá-la cognitivamente, o que justifica nosso interesse de obter uma maior compreensão acerca de determinadas características individuais, dentre as quais, mais especificamente, locus de controle, que porventura possam estar correlacionadas à felicidade.

Para uma melhor compreensão acerca do conceito de locus de controle, faz-se necessária a explicação de um conceito mais amplo, o qual chamamos de controle percebido. De acordo com Thompson (2002), controle percebido é, em linhas gerais, a concepção de um indivíduo de que ele dispõe de meios para obter os resultados que almeja, evitando aqueles os quais não deseja. Para esta mesma autora (2002) o controle percebido envolve duas dimensões distintas: locus de controle e auto eficácia. O conceito de auto-eficácia foi formalizado por Bandura (1977) e corresponde à crença de um indivíduo de que ele próprio possui habilidade para conduzir as ações necessárias a fim de atingir os resultados que deseja.

Locus de controle, por sua vez, trata-se de um constructo, introduzido na literatura psicológica a partir da década de sessenta, que pretende explicar a percepção do indivíduo a respeito de sua fonte de controle, podendo ser, esta última, 
oriunda do próprio sujeito (interna) ou de algum elemento fora de si próprio (externa) (Della Coleta, 1979). Nessa mesma linha, Corsini (2002) define locus de controle como sendo um ponto de vista que a pessoa possui em relação a sua autoindependência e controle dos outros sobre si. Sendo assim, um locus de controle interno se refere à convicção dessa pessoa de que ela pode usar seu próprio comportamento para conquistar os objetivos que deseja (Idem, 2002). Já um locus de controle externo corresponde à crença de que o verdadeiro poder se encontra fora da pessoa, e que as forças externas é que determinam sua vida. (Ibidem, 2002).

Para Thompson (2002) o controle percebido é a combinação de um locus de controle interno (o resultado depende de uma ação pessoal) com a auto-eficácia (possuo as habilidades para conduzir uma ação efetiva). No entanto, não podemos deixar de notar que a própria auto-eficácia também envolve um locus de controle interno, o que evidencia a grande proximidade entre os conceitos e a igualmente grande importância do conceito de locus de controle em particular, o que, em parte, justifica o escopo desta pesquisa.

Rotter (1966), responsável pelo desenvolvimento da primeira escala de mensuração de locus de controle, explica esse conceito da seguinte forma: 
Quando um reforço é percebido pelo sujeito como seguinte a uma ação sua, mas não sendo inteiramente contingente sobre sua ação, então, em nossa cultura, ele é tipicamente percebido como resultado de sorte, acaso, fé, assim como estando sob controle do poder dos outros, ou ainda é tido como imprevisível, em função da grande complexidade de forças que envolvem esse indivíduo. Quando uma pessoa interpreta o evento dessa forma, denominamos isso como uma crença no controle externo. Se a pessoa percebe que o evento é contingente em relação ao seu próprio comportamento ou a suas características relativamente permanentes, chamamos a isso de uma crença no controle interno.

Apesar de o locus de controle ter sido amplamente estudado, existe pouca convergência entre os resultados desses estudos (Fournier \& Jeanrie, 2003), o que pode ser explicado não apenas em função da variabilidade de instrumentos utilizados, mas também às diferentes direções nas quais autores diversos compreenderam o constructo (Idem, 2003).

Já na década de setenta, podemos encontrar críticas quanto à compreensão errônea de locus de controle. Phares (1976) afirma que, ao longo de sua evolução, esse constructo foi sendo incorretamente considerado como uma dimensão de personalidade estável. Além desse autor, Lefcourt (1976) afirma que locus de controle não é uma característica psicológica específica que se manifesta uniformemente através do tempo e das situações. 
No entanto, além da concepção caracterológica do conceito de locus de controle há outras idéias falsas que o cercam. Fournier \& Jeanrie (2003), afirmam que, de fato, o locus de controle tem sido freqüente e intrinsecamente considerado tanto positivo (se interno) quanto negativo (se externo). Segundo essas mesmas autoras a visão maniqueísta do locus de controle, bem como a glorificação da internalidade, suscitaram muitos debates acerca da natureza desse constructo, seu caráter unidimensional, sua generalidade e sua vulnerabilidade às normas sociais dominantes.

Rotter (1975) também foi um crítico em relação às concepções equivocadas que cercam o conceito de locus de controle. Numa dessas críticas, disse que os pesquisadores não consideram o valor do reforço como uma variável separada, capaz de provocar um viés na interpretação dos resultados. Nesse sentido, se uma pessoa atribui um baixo valor ao reforço, ela pode obter um alto índice de internalidade e, mesmo assim, continuar demonstrando uma atitude e um comportamento passivos, geralmente associados à externalidade (Fournier \& Jeanrie, 2003). Da mesma forma, se um alto valor é atribuído ao reforço, uma pessoa que obtém um alto índice de externalidade talvez trabalhe energicamente para atingir um objetivo (comportamento normalmente associado à internalidade) simplesmente para estar de acordo com um determinado grupo social (Idem, 2003).

Rotter (1975) também é um crítico em relação ao que chamou de hipersimplificação do conceito de locus de controle, o que acabou tendo como conseqüência o fato de a internalidade ser invariavelmente associada a elementos positivos e a externalidade a elementos negativos. 
Nesse sentido, Rotter procurou se contrapor a essa hipersimplificação de locus de controle e ilustrar os possíveis vieses na interpretação dos resultados das pesquisas a esse respeito, enfatizando a dificuldade na determinação de se é ou não uma alta internalidade que indica dificuldades de ajustamento, visto que um alto índice de internalidade pode indicar que o indivíduo julga ter mais poder para influenciar os eventos do que, de fato, possui (Fournier \& Jeanrie, 2003). Nesse caso, esse alto escore poderia estar indicando muito mais uma inabilidade para reconhecer suas limitações pessoais do que uma habilidade para confrontá-las (Idem, 2003). Por outro lado, ao pensarmos na relação entre locus de controle e felicidade, é difícil deixarmos de atribuir à internalidade um papel fundamental, sobretudo sob a ótica da psicologia cognitiva que vê a percepção como um dos fatores determinantes da relação entre o indivíduo e o meio que o cerca. Em outras palavras, poderíamos dizer que o bemestar subjetivo de uma pessoa é fortemente influenciado pela maneira como essa pessoa interpreta a realidade que a cerca, de forma que mais do que a própria realidade, será esta interpretação que determinará sua felicidade e, nesse sentido, a crença na internalidade exerce um papel importante.

Outro aspecto a ser considerado, diz respeito à dimensionalidade do conceito de locus de controle. Embora reconhecesse a existência de outros subfatores, Rotter (1975) defendia o caráter unidimensional do locus de controle, de forma que sua escala fornece uma medida geral que corresponde à extensão na qual a pessoa acredita exercer controle sobre sua própria vida ou o grau em que sente que seu destino está além de seu controle. No entanto, essa unidimensionalidade está longe de um consenso. 
Outros autores atribuem ao conceito de locus de controle um caráter multidimensional (Gurin, Gurin \& Morrison, 1978; Paulhus, 1983; Levenson, 1974).

Dentre estes, destacamos o trabalho de Levenson (1974) que afirma que o conceito de locus de controle deve ser separado em três fatores:

- Sensação de domínio sobre sua própria vida pessoal;

- Expectativa de controle sobre instituições políticas;

- Crença sobre o papel das forças internas e externas na sociedade em geral.

Segundo essa mesma autora, a razão por detrás dessa diferenciação tripartida advém do fato de que as pessoas que acreditam que o mundo é desordenado (ao acaso) deveriam se comportar e pensar diferentemente daqueles que acreditam que 0 mundo é ordenado, mas que os outros poderosos é que o controlam. Além disso, é esperado que uma pessoa que acredita que o acaso está no controle é cognitiva e comportamentalmente diferente daquela que sente que ela própria não está no controle (Idem, 1974). Nesse sentido, acreditamos que a mensuração de tais fatores em separado seja capaz de fornecer uma compreensão muito melhor acerca da percepção / atribuição do sujeito em relação àquilo que o controla.

Por fim, vale dizer, que o estudo do locus de controle encaixa-se perfeitamente bem dentro do paradigma da Psicologia Positiva, na medida em que enfatiza a identificação daquelas áreas nas quais o indivíduo pode exercer controle sobre seu próprio desenvolvimento e bem-estar psicológico, ao mesmo tempo em que reconhece que algumas situações ou eventos estão fora de seu controle, de forma 
que, contra eles não se deve lutar (Fournier \& Jeanrie, 2003). Reconhecendo a importância da subjetividade na compreensão das intrincadas forças internas e externas que determinam o que acontece a um indivíduo, um dos objetivos do psicólogo que trabalha com locus de controle é ajudar o indivíduo a descobrir e obter acesso a suas forças, enquanto escolhe ações capazes de promover sua saúde (Idem, 2003). Por essas razões pretendemos focar nosso estudo nas possíveis relações entre locus de controle e bem-estar subjetivo, buscando responder à seguinte questão: Indivíduos com locus de controle interno estariam mais propensos ao bemestar subjetivo? Nesse sentido, acreditamos que a resposta a essa pergunta poderá nos ajudar a compreender melhor os intrincados caminhos que levam à felicidade humana. 


\section{II - OBJETIVOS E HIPÓTESES}

\subsection{Objetivos}

O principal objetivo deste trabalho foi o de analisar a possível correlação entre bem-estar subjetivo e locus de controle. $O$ estudo desta relação justifica-se pelo que foi examinado no capítulo precedente que mostrou que o bem estar subjetivo está relacionado a múltiplos processos cognitivos e motivacionais que moderam o impacto do ambiente externo sobre o indivíduo. Acreditando nisso, desenvolvemos este estudo como uma forma de iniciar a investigação acerca dos processos relacionados à felicidade, de forma que estamos conscientes de que neste campo, ainda há muito o que ser pesquisado. Além disso, vimos que a polêmica existente entre a internalidade e a externalidade do locus de controle deixa em aberto a questão de se estas habilidades favoreceriam ou não a felicidade do indivíduo.

Em termos mais específicos, esta pesquisa teve também os seguintes objetivos:

a-) Avaliar o locus de controle da amostra estudada, através do instrumento descrito a seguir no item 4.2.

b-) Avaliar o bem-estar subjetivo da amostra estudada, através do instrumento descrito a seguir no item 4.2

c-) Determinar a ocorrência de flow na amostra estudada, utilizando-se para tanto, de questionário elaborado para este fim, conforme descrito a seguir no item 4.2.

d-) Analisar e discutir as possíveis relações entre as variáveis locus de controle, bem-estar subjetivo e ocorrência de flow. 


\subsection{Hipóteses}

A hipótese principal desta pesquisa antecipa que sujeitos com locus de controle interno estariam mais propensos a experienciar maiores índices de bem-estar subjetivo. Desta forma, a hipótese principal, em suas formulações nula e alternativa seriam:

$\mathrm{H}_{0}$ - O bem-estar subjetivo possui correlação positiva com o locus de controle interno; $\mathrm{H}_{1}$ - O bem-estar subjetivo não possui correlação positiva com o locus de controle interno.

Conforme discutimos no item 1.2.2, a experiência de flow aumenta a complexidade do self, o que, de acordo com a Psicologia Positiva, constitui-se numa peça-chave para a felicidade. Por isso, estabelecemos como hipótese secundária que a ocorrência de flow possui correlação positiva com o bem-estar subjetivo. 


\section{III- MÉTODO}

\subsection{SUJEITOS}

Participaram desta pesquisa um total de 106 sujeitos adultos, de ambos os sexos, estudantes de uma instituição de ensino superior particular da cidade de São Paulo, com nível superior em andamento ou completo, alunos dos cursos de Administração de Empresas, Ciências Contábeis e Secretariado Executivo Trilíngüe. As médias de idade e distribuição por gênero podem ser observadas nas duas tabelas a seguir:

Tabela 4: Distribuição dos Sujeitos por Idade

\begin{tabular}{|c|c|c|c|c|}
\hline \multirow[b]{2}{*}{ Idade } & \multicolumn{3}{|c|}{ Grupos de Idade } & \multirow{2}{*}{ Total } \\
\hline & 1 & 2 & 3 & \\
\hline 18 & 3 & 0 & 0 & 3 \\
\hline 19 & 12 & 0 & 0 & 12 \\
\hline 20 & 12 & 0 & 0 & 12 \\
\hline 21 & 14 & 0 & 0 & 14 \\
\hline 22 & 0 & 12 & 0 & 12 \\
\hline 23 & 0 & 5 & 0 & 5 \\
\hline 24 & 0 & 15 & 0 & 15 \\
\hline 25 & 0 & 0 & 5 & 5 \\
\hline 26 & 0 & 0 & 7 & 7 \\
\hline 27 & 0 & 0 & 5 & 5 \\
\hline 28 & 0 & 0 & 2 & 2 \\
\hline 29 & 0 & 0 & 3 & 3 \\
\hline 30 & 0 & 0 & 2 & 2 \\
\hline 31 & 0 & 0 & 3 & 3 \\
\hline 33 & 0 & 0 & 2 & 2 \\
\hline 34 & 0 & 0 & 1 & 1 \\
\hline 35 & 0 & 0 & 1 & 1 \\
\hline 45 & 0 & 0 & 1 & 1 \\
\hline \multirow[t]{2}{*}{48} & 0 & 0 & 1 & 1 \\
\hline & 41 & 32 & 33 & 106 \\
\hline
\end{tabular}

Fonte: SPSS 
Conforme podemos observar na tabela 4, os 106 sujeitos foram classificados em três grupos etários a saber:

Grupo 1: 18 a 21 anos - (total de 41 sujeitos)

Grupo 2: 22 a 24 anos - (total de 32 sujeitos)

Grupo 3: 25 anos ou mais - (total de 33 sujeitos)

\section{Tabela 5: Distribuição dos Sujeitos por Gênero}

\begin{tabular}{|c|c|c|}
\hline & $\mathbf{F}$ & $\%$ \\
\hline Masculino & 26 & 24.5 \\
\hline Feminino & 80 & 75.5 \\
\hline Total & 106 & 100 \\
\hline
\end{tabular}

Fonte: SPSS

Quanto à distribuição por gênero, a tabela 5 indica que $24,5 \%$ da nossa amostra era formada por pessoas do sexo masculino e $75,5 \%$ do sexo feminino. Esta diferença em favor do sexo feminino se explica devido ao fato de muitos sujeitos da pesquisa estarem matriculados no curso de Secretariado Executivo Trilíngüe da Instituição pesquisada, curso quase que exclusivamente freqüentado por mulheres.

Tabela 6: Classificação econômica dos sujeitos

\begin{tabular}{|c|c|c|}
\hline Classe & F & $\%$ \\
\hline A1 & 4 & 3.8 \\
\hline A2 & 9 & 8.5 \\
\hline B1 & 30 & 28.3 \\
\hline B2 & 35 & 33 \\
\hline C & 26 & 24.5 \\
\hline D & 2 & 1.9 \\
\hline E & 0 & 0 \\
\hline Total & 106 & 100 \\
\hline
\end{tabular}

Fonte: SPSS 
A classificação econômica dos sujeitos, realizada através do Critério de Classificação Econômica Brasil (CCEB), pode ser melhor visualizada na tabela 6, através da qual observamos uma grande concentração de sujeitos distribuídos entre as classes B1, B2 e C. Apenas para efeito de uma melhor caracterização de nossa amostra, vale dizer que a renda familiar média dessas três classes econômicas costuma, de acordo com dados da Associação Nacional de Empresas de Pesquisa, variar entre $R \$ 927,00$ a $R \$ 2.804,00$. Trata-se de um resultado de certa forma esperado, uma vez que o público da Instituição pesquisada é formado por pessoas da chamada classe média brasileira. Vale dizer que tal característica deve ser levada em consideração ao tirarmos conclusões acerca deste estudo.

Todavia, no capítulo seguinte, uma descrição mais pormenorizada acerca do Critério de Classificação Econômica Brasil nos permitirá compreendermos ainda melhor nossa amostra e até que ponto a mesma é capaz de retratar a realidade brasileira. 


\subsection{INSTRUMENTOS}

\subsubsection{Critério de Classificação Econômica Brasil}

O Critério de Classificação Econômica Brasil (CCEB) tem por objetivo a segmentação da população brasileira em função de seu poder de compra, ou seja, das chamadas classes econômicas (Appolinário, 2004). Desenvolvido desde a década de setenta, este critério tem sofrido diversas revisões, sendo que nesta pesquisa, utilizamos sua versão mais atual (anexo I), proposta pela Associação Brasileira de Empresas de Pesquisa - ANEP (2004) e que tem por objetivo unificar todas as formas anteriores de classificação.

Optamos pela utilização do Critério de Classificação Econômica Brasil porque além de se tratar de um critério amplamente aceito pela comunidade científica, tratase de um critério eminentemente brasileiro, fundamentado no Levantamento Sócioeconômico do IBOPE e que, por essa razão, oferece-nos melhores condições de análise da realidade de nosso país.

Conforme podemos observar na tabelas 7 e 8, a classificação do CCEB é feita através de um sistema de pontuação que leva em consideração dois grandes fatores: o nível de escolaridade do chefe da família e a presença de determinados itens na residência do sujeito pesquisado (Appolinário, 2004). 
Tabela 7 - Sistema de Pontuação CCEB para posse de itens.

\begin{tabular}{|l|c|c|c|c|c|}
\hline & NÃO & \multicolumn{5}{|c|}{ TEM } \\
\cline { 3 - 6 } & TEM & $\mathbf{1}$ & $\mathbf{2}$ & $\mathbf{3}$ & $\mathbf{4}$ ou + \\
\hline Televisão em cores & 0 & 2 & 3 & 4 & 5 \\
\hline Rádio (exceto do carro) & 0 & 1 & 2 & 3 & 4 \\
\hline Banheiro & 0 & 2 & 3 & 4 & 4 \\
\hline Automóvel * & 0 & 2 & 4 & 5 & 5 \\
\hline Empregada Mensalista & 0 & 2 & 4 & 4 & 4 \\
\hline Aspirador de pó & 0 & 1 & 1 & 1 & 1 \\
\hline Máquina de lavar roupa & 0 & 1 & 1 & 1 & 1 \\
\hline Vídeo cassete e/ou DVD & 0 & 2 & 2 & 2 & 2 \\
\hline Geladeira & 0 & 2 & 2 & 2 & 2 \\
\hline $\begin{array}{l}\text { Freezer (aparelho independente } \\
\text { ou parte de geladeira duplex) }\end{array}$ & 0 & 1 & 1 & 1 & 1 \\
\hline
\end{tabular}

Fonte: Associação Nacional de Empresas de Pesquisa (1996)

Tabela 8 - Sistema de Pontuação CCEB para nível de instrução.

\begin{tabular}{|l|c|}
\hline Analfabeto / Primário Incompleto & 0 \\
\hline Primário Completo / Ginasial Incompleto & 1 \\
\hline Ginasial Completo / Colegial Incompleto & 2 \\
\hline Colegial Completo / Superior Incompleto & 3 \\
\hline Superior Completo & 5 \\
\hline Fonte: Associação Nacional de Empresas de Pesquisa (1996)
\end{tabular}

Desta forma, somando-se a pontuação total do sujeito nas duas categorias apresentadas, é possível classificá-lo de acordo com sua classe econômica, conforme podemos observar na tabela 9: 


\section{Tabela 9 - Cortes do Critério Brasil}

\begin{tabular}{|c|c|c|}
\hline CLASSE & PONTOS & \% BRASIL \\
\hline $\mathrm{A} 1$ & $30-34$ & 1 \\
\hline A2 & $25-29$ & 5 \\
\hline B1 & $21-24$ & 9 \\
\hline B2 & $17-20$ & 14 \\
\hline $\mathrm{C}$ & $11-16$ & 36 \\
\hline $\bar{D}$ & $6-10$ & 31 \\
\hline $\mathrm{E}$ & $0-5$ & 4 \\
\hline
\end{tabular}

Conforme já dissemos, $85,8 \%$ da nossa amostra enquadra-se nas classes B1, B2 e C. Como podemos observar na tabela acima, essas três classes juntas correspondem apenas a $59 \%$ da população brasileira. Isso corrobora o já mencionado cuidado que devemos ter ao generalizarmos os resultados deste estudo.

\subsubsection{Escala de Locus de Controle de Levenson}

Para a avaliação do locus de controle foi utilizada a escala de Levenson (1974) (anexo I) devido ao fato de esta escala permitir uma análise tripartida do constructo que se propõe avaliar, permitindo, assim, uma melhor compreensão acerca do fenômeno. Dessa forma, trata-se de um instrumento que se propõe a medir 3 categorias distintas: controle interno (C.I), controle externo (C.E) e controle do acaso (C.A). De acordo com Levenson (1974) a divisão da escala nessas 3 categorias se justifica devido à diferença existente entre o comportamento e pensamento de um indivíduo que acredita que a vida é controlada pelo acaso (sorte) daquele que julga que sua vida está sob controle do que chamamos de "outros poderosos".

Sendo assim, a escala de locus de controle de Levenson tem seus 24 itens distribuídos da seguinte forma: 

a) Controle Interno (C.I): questões de número 1, 4, 5, 9, 18, 19, 21 e 23.
b) Controle Externo (C.E): questões de número 3, 8, 11, 13, 15, 17, 20 e 22
c) Controle do Acaso (C.A): questões de número 2, 6, 7, 10, 12, 14, 16 e 24.

\subsubsection{Escala Geral de Felicidade de Lyubomirsky \& Lepper}

Já quanto ao bem-estar subjetivo, optamos por um instrumento de avaliação geral, já que estamos interessados na avaliação global que os sujeitos fazem de sua vida, no tocante à felicidade que experimentam. Por essa razão, utilizamos a escala geral de felicidade subjetiva de Lyubomirsky \& Lepper (1999) (anexo II). Considerando a característica de auto-relato do instrumento, seria legítima a preocupação quanto à sua validade pois, em tese, as pessoas poderiam dizer que são felizes, ainda que, de fato, experimentassem baixo índice de bem-estar subjetivo. No entanto, um estudo conduzido por Sandvik, Diener \& Seidlitz (1993) mostrou que as medidas de autorelato convergem com outros tipos de avaliação, que incluem medidas de amostragem experimental, depoimentos de família e amigos e levantamento de memória dos sujeitos para eventos positivos e negativos.

\subsubsection{Questionário de Identificação de Flow}

Quanto ao levantamento acerca da ocorrência de flow, o mesmo será feito através de um questionário (anexo III) o qual foi elaborado com base na literatura pesquisada considerando, sobretudo, as condições para o flow, propostas por Nakamura \& Csikszentmihalyi (2002), e discutidas no capítulo 1.2.2. 
Trata-se de um questionário composto por um total de 7 perguntas, sendo 5 fechadas e 2 abertas. A inserção das questões abertas objetivou favorecer uma maior percepção acerca da qualidade da experiência autotélica, fundamental para que pudéssemos diferenciá-la do flow, determinando a ocorrência ou não deste último.

\subsection{PROCEDIMENTO}

Os participantes da pesquisa receberam, inicialmente, cópia do consentimento informado (anexo IV) cujo objetivo discutiremos no item 4.5.

Isto posto, a avaliação dos sujeitos deu-se através da aplicação coletiva dos testes descritos no item 4.2, que foram aplicados obedecendo a uma ordem préestabelecida que, ao deixar as perguntas mais específicas para o final, pretendeu eliminar possíveis viéses que as mesmas poderiam provocar. Dessa forma, os instrumentos foram aplicados na seguinte ordem:

$\left.1^{\circ}\right)$ Critério de Classificação Econômica Brasil;

$\left.2^{\circ}\right)$ Escala Geral de Felicidade;

3) Questionário de Flow

$4^{\circ}$ ) Escala de Locus de Controle de Levenson. 


\subsection{CONSIDERACÕ̃ES ÉTICAS}

Embora os procedimentos relatados no item 4.3. não ofereçam nenhum tipo de risco aos sujeitos participantes, achamos por bem que todos os sujeitos tomassem ciência dos objetivos e condições gerais de realização desta pesquisa, através da assinatura de um documento denominado consentimento informado (anexo II), cuja cópia foi oferecida a cada um dos sujeitos, conforme recomendações da literatura em relação à ética na realização de pesquisas com sujeitos humanos (MINISTÉRIO DA SAÚDE, 1997; WORLD HEALTH ORGANIZATION, 1993). 


\section{IV- RESULTADOS}

\subsection{Dados Qualitativos:}

Em relação ao flow, procedemos a uma análise qualitativa dos dados obtidos através do questionário, a fim de que pudéssemos verificar se cada sujeito, individualmente, era capaz de experimentar momentos de flow, conforme este conceito fora descrito no capítulo 1.2.2. Percebemos, durante a tabulação dos dados, uma grande influência que a metacognição parece exercer sobre o flow, na medida em que, como vimos, as condições para sua ocorrência incluem desafios percebidos pelo indivíduo como adequados a suas habilidades, bem como um feedback constante acerca de seus progressos na atividade executada. Isso significa ser possível que um sujeito tenha respondido que a atividade autotélica na qual costuma se engajar não exige de suas habilidades pessoais, não porque ela efetivamente não o faça, mas apenas por ignorar quais são suas habilidades. Isso aponta para uma importante limitação do instrumento utilizado para a mensuração do flow que deve ser levada em conta antes de tirarmos conclusões definitivas. Ainda assim optamos por utilizar o instrumento, seguindo os critérios que apresentaremos a seguir e que foram estabelecidos a partir das características do flow descritas no capítulo 1.2.2.:

1- A ocorrência de atividade autotélica é condição de exclusão para a experiência de flow;

2- A qualidade da experiência vivida (avaliada através das questões abertas) é muito mais determinante da experiência de flow do que a consciência do indivíduo acerca da exigência ou não de suas habilidades pessoais, bem como do grau em que as mesmas foram exigidas. 
Sendo assim, após analisar cada caso, identificamos quais dos sujeitos haviam experimentado o flow, fazendo com que este se transformasse numa variável nominal em nosso estudo.

\subsection{Dados Quantitativos:}

Uma vez obtidos os dados, os mesmos foram sumarizados por meio das técnicas da estatística descritiva, conforme podemos visualizar através das tabelas 10 a 16:

\section{Tabela 10- Estatísticas Descritivas das Variáveis}

\begin{tabular}{|c|c|c|c|c|c|c|c|}
\hline & \multicolumn{2}{|c|}{$\mathrm{N}$} & \multirow[b]{2}{*}{ Média } & \multirow[b]{2}{*}{ Mediana } & \multirow[b]{2}{*}{ Desvio Padrão } & \multirow{2}{*}{$\begin{array}{l}\text { Valor } \\
\text { Mínimo }\end{array}$} & \multirow{2}{*}{$\begin{array}{l}\text { Valor } \\
\text { Máximo }\end{array}$} \\
\hline & Válidos & Inválidos & & & & & \\
\hline $\begin{array}{l}\text { Nível Sócio } \\
\text { Econômico }\end{array}$ & 106 & 0 & 3,28 & 3,00 & 1,102 & 1 & 6 \\
\hline Felicidade & 106 & 0 & 5,0613 & 5,0000 & 1,03614 & 2,00 & 7,00 \\
\hline $\begin{array}{l}\text { Controle } \\
\text { Interno }\end{array}$ & 106 & 0 & 5,91 & 6,00 & 1,291 & 2 & 8 \\
\hline $\begin{array}{l}\text { Controle } \\
\text { Externo }\end{array}$ & 106 & 0 & 1,58 & 1,00 & 1,567 & 0 & 7 \\
\hline $\begin{array}{l}\text { Controle } \\
\text { Acaso }\end{array}$ & 106 & 0 & 1,87 & 1,50 & 1,592 & 0 & 8 \\
\hline
\end{tabular}

A tabela 10 apresenta as estatísticas descritivas para as variáveis "Nível Sócioeconômico (NSE)"; "Felicidade"; "Controle Interno"; "Controle Externo" e "Controle do Acaso". Para que possamos compreender a média e a mediana de cada variável (bem como as demais tabelas que virão a seguir), é fundamental observarmos o valor mínimo e o valor máximo de cada uma delas, que devem ser compreendidos como se fossem valores de uma escala likert e que diferem entre si por terem sido mensurados através de diferentes instrumentos, os quais já foram devidamente apresentados no capítulo 3.2. De qualquer forma, acreditamos caber uma breve explicação acerca desses valores: 
IV- Resultados

Variável NSE: Conforme já dissemos na sessão anterior, nossa amostra encontra-se dividida entre as classes $D, C, B 2, B 1, A 2$ e $A 1$, sendo que nenhum dos sujeitos enquadrou-se na classe $E$ do critério de classificação utilizado (CCEB). A fim de viabilizar nossos cálculos com relação a esta variável, numeramos as classes econômicas, respeitando sua hierarquia, ou seja: 1,2,3,4,5 e 6 respectivamente, onde a classe mais baixa $D$ recebeu o número 1 e a mais alta, $A 1$, recebeu o número 6 . Assim ao dizermos, conforme nos mostra a tabela 10, que a média da variável NSE foi de 3,28, estamos dizendo que a média dos sujeitos situa-se entre as classes econômicas B2 e B1.

Variável Felicidade: Conforme pudemos observar no item 3.2.3., esta variável mensurada través de um instrumento composto por 4 questões cujas respostas variavam numa escala likert de 1 a 7 . Isso significa que, ao somarmos os pontos relativos a cada questão e dividirmos esse total por 4 , chegamos a um valor que representa a média de felicidade ou bem-estar-subjetivo de cada sujeito. Esse valor médio (que obviamente varia de 1 a 7) compõe a variável felicidade deste estudo.

Variáveis Controle Interno, Controle Externo e Controle Acaso: Essas três variáveis foram mensuradas através da já apresentada (item 3.2.2.) escala de Locus de Controle de Levenson. Conforme pudemos observar, o instrumento é composto por 24 afirmações, sendo que cada um dos três componentes do locus de controle é avaliado através de 8 dessas afirmações, cujas respostas demandam apenas que 0 indivíduo concorde ou discorde delas. Sendo assim, consideramos que um sujeito que concordou com todas as afirmações relativas ao locus de controle interno, obteve um escore de 8 para a variável controle interno, ao passo que se o mesmo indivíduo discordou de todas as afirmações relativas ao controle do acaso, obteve um escore de 0 nesta variável. Isso significa que, ao estabelecermos um valor mínimo e um valor máximo para cada uma dessas variáveis, estamos trabalhando com uma escala Likert que nos mostra o grau em que os sujeitos apresentam o constructo expresso pelas variáveis. 


\section{Tabela 11 - Distribuição de Freqüência da Variável Felicidade}

\begin{tabular}{|c|c|c|c|c|}
\hline $\begin{array}{c}\text { Nível } \\
\text { do } \\
\text { Item }\end{array}$ & Freqüência & Percentual & $\begin{array}{l}\text { Percentual } \\
\text { Válido }\end{array}$ & $\begin{array}{l}\text { Percentual } \\
\text { Acumulado }\end{array}$ \\
\hline 2,00 & 1 & ,9 & ,9 & ,9 \\
\hline 2,25 & 2 & 1,9 & 1,9 & 2,8 \\
\hline 2,50 & 1 & ,9 & ,9 & 3,8 \\
\hline 2,75 & 1 & ,9 & ,9 & 4,7 \\
\hline 3,25 & 1 & ,9 & ,9 & 5,7 \\
\hline 3,50 & 1 & ,9 & ,9 & 6,6 \\
\hline 3,75 & 2 & 1,9 & 1,9 & 8,5 \\
\hline 4,00 & 6 & 5,7 & 5,7 & 14,2 \\
\hline 4,25 & 12 & 11,3 & 11,3 & 25,5 \\
\hline 4,50 & 8 & 7,5 & 7,5 & 33,0 \\
\hline 4,75 & 7 & 6,6 & 6,6 & 39,6 \\
\hline 5,00 & 15 & 14,2 & 14,2 & 53,8 \\
\hline 5,25 & 5 & 4,7 & 4,7 & 58,5 \\
\hline 5,50 & 9 & 8,5 & 8,5 & 67,0 \\
\hline 5,75 & 11 & 10,4 & 10,4 & 77,4 \\
\hline 6,00 & 6 & 5,7 & 5,7 & 83,0 \\
\hline 6,25 & 8 & 7,5 & 7,5 & 90,6 \\
\hline 6,50 & 7 & 6,6 & 6,6 & 97,2 \\
\hline 6,75 & 1 & ,9 & ,9 & 98,1 \\
\hline 7,00 & 2 & 1,9 & 1,9 & 100,0 \\
\hline Total & 106 & 100,0 & 100,0 & \\
\hline
\end{tabular}

Fonte: SPSS

A tabela 11 nos mostra a distribuição da freqüência de respostas da variável "Felicidade". Lembrando que esta variável possui um valor mínimo de 2 e o máximo de 7, conforme já explicamos, a coluna "nível do item" corresponde aos valores intermediários obtidos pelos sujeitos, considerando o total de pontos que cada um deles obteve no instrumento descrito no item 3.2.3. 
IV- Resultados

\section{Tabela 12 - Distribuição de Freqüência da Variável Controle Interno}

\begin{tabular}{|c|c|c|c|c|}
\hline $\begin{array}{c}\text { Nível } \\
\text { do } \\
\text { Item }\end{array}$ & Freqüência & Percentual & $\begin{array}{c}\text { Percentual } \\
\text { Válido }\end{array}$ & $\begin{array}{l}\text { Percentual } \\
\text { Acumulado }\end{array}$ \\
\hline 2 & 2 & 1,9 & 1,9 & 1,9 \\
\hline 3 & 2 & 1,9 & 1,9 & 3,8 \\
\hline 4 & 10 & 9,4 & 9,4 & 13,2 \\
\hline 5 & 22 & 20,8 & 20,8 & 34,0 \\
\hline 6 & 33 & 31,1 & 31,1 & 65,1 \\
\hline 7 & 28 & 26,4 & 26,4 & 91,5 \\
\hline 8 & 9 & 8,5 & 8,5 & 100,0 \\
\hline Total & 106 & 100,0 & 100,0 & \\
\hline
\end{tabular}

Conforme observamos na tabela 12, o nível do item Controle Interno variou apenas de 2 a 8 , muito embora, conforme já explicamos, o mesmo pudesse, em tese, variar de 0 a 8 , sendo que o escore 0 seria dado ao sujeito que discordasse de todas as 8 afirmações contidas no instrumento, com o objetivo de mensurar este determinado aspecto do locus de controle. Porém como se trata de uma tabela de distribuição de freqüência, devemos considerar apenas as respostas efetivamente dadas pelos sujeitos. Isso significa que, ao responder o instrumento, nenhum sujeito da amostra discordou de menos do que duas das afirmativas correspondentes ao controle interno. Vale ressaltar ainda que, numa escala de 0 a $8,86,8 \%$ dos nossos sujeitos apresentam um locus de controle interno acima de 5 .

No entanto, esse resultado nos diz muito pouco se tomado isoladamente. Isso ocorre, em primeiro lugar, devido às próprias limitações dos instrumentos de autorelato que nem sempre avaliam aquilo que o sujeito efetivamente é, mas sim aquilo que ele desejaria ser ou aquilo que ele julga ser mais bem aceito socialmente. Em segundo lugar, e conforme já exposto no item 3.2.2., o locus de controle de um indivíduo é produto das três dimensões avaliadas na Escala de Levenson, e não apenas de uma delas. 


\section{Tabela 13 - Distribuição de Freqüência da Variável Controle Externo}

\begin{tabular}{|l|r|r|r|r|}
\hline $\begin{array}{c}\text { Nível } \\
\text { do } \\
\text { Item }\end{array}$ & Freqüência & Percentual & $\begin{array}{c}\text { Percentual } \\
\text { Válido }\end{array}$ & $\begin{array}{c}\text { Percentual } \\
\text { Acumulado }\end{array}$ \\
\hline 0 & 27 & 25,5 & 25,5 & 25,5 \\
1 & 35 & 33,0 & 33,0 & 58,5 \\
2 & 24 & 22,6 & 22,6 & 81,1 \\
3 & 8 & 7,5 & 7,5 & 88,7 \\
4 & 7 & 6,6 & 6,6 & 95,3 \\
6 & 3 & 2,8 & 2,8 & 98,1 \\
7 & 2 & 1,9 & 1,9 & 100,0 \\
Total & 106 & 100,0 & 100,0 & \\
\hline
\end{tabular}

De acordo com a tabela 13, com relação à variável "Controle Externo", observamos uma situação inversa: 86\% da amostra apresenta, numa escala de 0 a 8 , um nível de até 2 de controle externo. Esse resultado, aliado ao que obtivemos quanto ao controle interno, não chega a surpreender, considerando-se o tipo de cultura da sociedade ocidental contemporânea que enfatiza a autonomia do sujeito em relação à sua própria vida.

\section{Tabela 14 - Distribuição de Freqüência da Variável Controle Acaso}

\begin{tabular}{|l|r|r|r|r|}
\hline $\begin{array}{c}\text { Nível } \\
\text { do } \\
\text { Item }\end{array}$ & Freqüência & Percentual & $\begin{array}{c}\text { Percentual } \\
\text { Válido }\end{array}$ & $\begin{array}{r}\text { Percentual } \\
\text { Acumulado }\end{array}$ \\
\hline 0 & 23 & 21,7 & 21,7 & 21,7 \\
1 & 30 & 28,3 & 28,3 & 50,0 \\
2 & 18 & 17,0 & 17,0 & 67,0 \\
3 & 16 & 15,1 & 15,1 & 82,1 \\
4 & 15 & 14,2 & 14,2 & 96,2 \\
5 & 2 & 1,9 & 1,9 & 98,1 \\
6 & 1 &, 9 &, 9 & 99,1 \\
8 & 1 &, 9 &, 9 & 100,0 \\
Total & 106 & 100,0 & 100,0 & \\
\hline
\end{tabular}

No tocante à variável "Controle do Acaso" observamos na tabela 14 uma distribuição mais equilibrada, sugerindo que os sujeitos admitem mais a influência do caso em suas vidas do que a de outras pessoas. 
IV- Resultados

\section{Tabela 15 - Distribuição de Freqüência da Variável Flow}

\begin{tabular}{|l|r|r|r|r|}
\hline $\begin{array}{c}\text { Nível } \\
\text { do } \\
\text { Item }\end{array}$ & Freqüência & Percentual & $\begin{array}{c}\text { Percentual } \\
\text { Válido }\end{array}$ & $\begin{array}{r}\text { Percentual } \\
\text { Acumulado }\end{array}$ \\
\hline 1 & 50 & 47,2 & 47,2 & 47,2 \\
2 & 56 & 52,8 & 52,8 & 100,0 \\
Total & 106 & 100,0 & 100,0 & \\
\hline
\end{tabular}

A tabela 15 indica que 47,2\% da amostra não costuma experienciar momentos de flow, enquanto que com $52,8 \%$ ocorre o contrário. Conforme já dissemos, para que conseguíssemos transformar o flow numa variável nominal, fizemos uma análise qualitativa do questionário que elaboramos para este fim e que fora descrito no item 3.2.4. a fim de chegarmos a uma conclusão simples: "O sujeito possui momentos de flow em sua vida"?

Contudo, este resultado deve ser visto com reservas, devido às limitações já discutidas no item 4.1. Apesar de tais limitações, optamos por continuar a trabalhar com esta variável visto que, na maioria dos casos, os questionários foram elucidativos quanto à ocorrência ou não do flow.

Depois de verificar a distribuição de freqüência das variáveis procedemos, em seguida, a uma análise acerca da normalidade ou não dos dados das diferentes variáveis, utilizando-nos, para tanto, do teste Kolmogorov-Smirnov, cujos resultados podem ser visualizados na tabela a seguir: 


\section{Tabela 16 - Teste Kolmogorov-Smirnov para Aderência à Distribuição Normal}

\begin{tabular}{|l|r|r|}
\hline & Kolmogorov-Smirnov Z & Asymp. Sig. (2-tailed) \\
\hline Sexo & 4,834 &, 000 \\
Idade & 1,763 &, 004 \\
Nível Sócio & 2,015 &, 001 \\
Econômico & & \\
Controle & 1,951 &, 001 \\
Interno &, 825 &, 503 \\
Felicidade & 2,349 &, 000 \\
Controle & 2,133 &, 000 \\
Externo & 2,803 &, 000 \\
Controle & & \\
Acaso & & \\
Flow & & \\
\hline
\end{tabular}

Fonte: SPSS

De acordo com este teste, um nível de significância maior do que 0,05 é indicativo de aderência à Distribuição Normal (SPSS, 2003). Conforme se pode observar, dentre todas as testadas, apenas a variável Felicidade se encaixa nessa condição. Optamos, portanto, pela utilização de testes não-paramétricos, uma vez que os mesmos também podem ser aplicados em dados paramétricos, sendo que o contrário não é verdadeiro (Siegel, 1979).

Sendo assim, procedemos à análise de correlação utilizando o teste de Spearman, cujos resultados apresentamos na tabela seguinte. 
Tabela 17- Correlações de Spearman

\begin{tabular}{|c|c|c|c|c|c|c|c|}
\hline & & flow & catotal & cetotal & citotal & classeco & $\begin{array}{c}\text { Grau } \\
\text { Felicidade }\end{array}$ \\
\hline \multirow[t]{3}{*}{ flow } & Coef. Correl. & 1,000 &,- 034 &,- 034 & ,119 &, 012 & ,127 \\
\hline & Significância & & ,731 & ,733 & ,225 & ,904 & 194 \\
\hline & $\mathrm{N}$ & 106 & 106 & 106 & 106 & 106 & 106 \\
\hline \multirow[t]{3}{*}{ catotal } & Coef. Correl. &,- 034 & 1,000 &, $505\left(^{\star \star}\right)$ &,- 104 & ,012 &,- 186 \\
\hline & Significância &, 731 & &, 000 & ,290 & ,900 & ,056 \\
\hline & $\mathrm{N}$ & 106 & 106 & 106 & 106 & 106 & 106 \\
\hline \multirow[t]{3}{*}{ cetotal } & Coef. Correl. &,- 034 &, $\left.505^{(* *}\right)$ & 1,000 &,- 177 & ,005 &,$\left.- 326{ }^{(* *}\right)$ \\
\hline & Significância & ,733 &, 000 & & ,070 & ,957 &, 001 \\
\hline & $\mathrm{N}$ & 106 & 106 & 106 & 106 & 106 & 106 \\
\hline \multirow[t]{3}{*}{ citotal } & Coef. Correl. & , 119 &,- 104 &,- 177 & 1,000 & 182 &, $335\left(^{* *}\right)$ \\
\hline & Significância & ,225 & 290 & ,070 & & ,061 &, 000 \\
\hline & $\mathrm{N}$ & 106 & 106 & 106 & 106 & 106 & 106 \\
\hline \multirow[t]{3}{*}{ classeco } & Coef. Correl. & ,012 & ,012 & ,005 & , 182 & 1,000 &, $242\left(^{*}\right)$ \\
\hline & Significância & ,904 & ,900 & ,957 & ,061 & &, 013 \\
\hline & $\mathrm{N}$ & 106 & 106 & 106 & 106 & 106 & 106 \\
\hline \multirow{3}{*}{$\begin{array}{l}\text { Grau de } \\
\text { Felicidade }\end{array}$} & Coef. Correl. & 127 &,- 186 &,$- 326(* *)$ &, $\left.335{ }^{* \star}\right)$ & ,242(*) & 1,000 \\
\hline & Significância & , 194 & ,056 & ,001 & ,000 & 013 & \\
\hline & $\mathrm{N}$ & 106 & 106 & 106 & 106 & 106 & 106 \\
\hline
\end{tabular}

** Correlação significante $(p<=0,01)$.

* Correlação significante $(p<=0,05)$.

Conforme mostra a tabela acima, observamos uma moderada correlação positiva entre as variáveis "Grau de felicidade" e "Controle Interno" $(r=0,335 ; p \leq 0,01)$, ao mesmo tempo em que pudemos verificar uma moderada correlação negativa entre "Grau de Felicidade" e "Controle Externo" ( $r=0,326 ; p \leq 0,01)$. A partir desse resultado, achamos por bem investigar mais profundamente tais correlações, utilizando-nos, para tanto, de um teste estatístico de caráter inferencial e que, portanto, nos permite chegar a conclusões mais confiáveis. Escolhemos o teste de Kruskal-Wallis por este ser bastante útil para descobrir se um determinado número de amostras independentes provém ou não de populações diferentes (Siegel, 1979). 
Considerando que os valores amostrais quase sempre diferem entre si, a prova de Kruskal-Wallis responde se as diferenças entre as amostras significam diferenças efetivas entre as populações, ou se representam apenas variações casuais, passíveis de serem encontradas em amostras aleatórias de uma mesma população (Idem, 1979). Vale dizer, ainda, que o teste de Kruskal-Wallis é uma das mais eficientes provas não-paramétricas para um determinado número de amostras independentes, com poder-eficiência de 95,5\% (Ibidem, 1979), principal razão pela qual decidimos por sua utilização. As tabelas 18 a 21 demonstram os resultados encontrados através desse teste.

Tabela 18 - Ranqueamento do Teste Kruskal-Wallis para as variáveis Controle Interno e Controle Externo, com respeito à variável de Grupo Felicidade.

\begin{tabular}{|l|l|r|r|}
\hline & \multicolumn{1}{|c|}{ Felicidade } & $\mathrm{N}$ & $\begin{array}{c}\text { Ranqueamento } \\
\text { Médio }\end{array}$ \\
\hline $\begin{array}{l}\text { Controle } \\
\text { Externo }\end{array}$ & 2,00 & 5 & 79,00 \\
\hline & 3,00 & 4 & 60,00 \\
\hline & 4,00 & 33 & 60,89 \\
\hline & 5,00 & 40 & 53,06 \\
\hline & 6,00 & 22 & 35,66 \\
\hline & 7,00 & 2 & 59,75 \\
\hline Controle & Total & 106 & 27,30 \\
\hline & 2,00 & 5 & 21,50 \\
\hline & 3,00 & 4 & 46,59 \\
\hline & 4,00 & 33 & 59,21 \\
\hline & 5,00 & 40 & 61,68 \\
\hline & 6,00 & 22 & 92,75 \\
\hline & 7,00 & 2 & \\
\hline & Total & 106 & \\
\hline
\end{tabular}

Fonte: SPSS 
Tabela 19 - Teste H de Kruskal-Wallis para as variáveis Controle Interno e Controle Externo, com respeito à variável de Grupo Felicidade.

\begin{tabular}{|l|r|r|}
\hline & $\begin{array}{c}\text { Controle } \\
\text { Externo }\end{array}$ & $\begin{array}{c}\text { Controle } \\
\text { Interno }\end{array}$ \\
\hline $\begin{array}{l}\text { Qui- } \\
\text { quadrado }\end{array}$ & 13,930 & 16,822 \\
\hline GL & 5 & 5 \\
\hline Sig. &, 016 &, 005 \\
\hline
\end{tabular}

a Kruskal Wallis Test

b Variável de Grupo: Felicidade

Fonte:SPSS

Conforme podemos observar nas tabelas 18 e 19 referentes ao teste de Kruskal-Wallis, os graus de Controle Interno e Externo aparecem como discriminantes em relação à variável Felicidade $(H=16,82 ; p \leq 0,005)$ e $(H=13,93 ; p \leq 0,016)$, respectivamente, porém em sentidos opostos. Em outras palavras, isso significa que, na amostra estudada, quanto maior a sensação de controlar sua própria vida (locus de controle interno) o indivíduo apresentou, maior também foram seus níveis de felicidade, enquanto que o controle externo manteve com a variável felicidade, uma relação inversamente proporcional. 
Tabela 20 - Ranqueamento do Teste Kruskal-Wallis para as variáveis Controle do Acaso, Flow, NSE, Idade e Sexo, com respeito à variável de Grupo Felicidade.

\begin{tabular}{|c|c|c|c|}
\hline & Felicidade & $\mathrm{N}$ & $\begin{array}{l}\text { Ranqueamento } \\
\text { Médio }\end{array}$ \\
\hline \multirow[t]{7}{*}{ Sexo } & 2,00 & 5 & 55,90 \\
\hline & 3,00 & 4 & 66,50 \\
\hline & 4,00 & 33 & 53,65 \\
\hline & 5,00 & 40 & 51,93 \\
\hline & 6,00 & 22 & 54,45 \\
\hline & 7,00 & 2 & 40,00 \\
\hline & Total & 106 & \\
\hline \multirow[t]{7}{*}{ Idade } & 2,00 & 5 & 56,60 \\
\hline & 3,00 & 4 & 61,13 \\
\hline & 4,00 & 33 & 49,71 \\
\hline & 5,00 & 40 & 54,95 \\
\hline & 6,00 & 22 & 55,43 \\
\hline & 7,00 & 2 & 42,75 \\
\hline & Total & 106 & \\
\hline \multirow[t]{7}{*}{$\begin{array}{l}\text { Nível Sócio } \\
\text { Econômico }\end{array}$} & 2,00 & 5 & 34,20 \\
\hline & 3,00 & 4 & 35,38 \\
\hline & 4,00 & 33 & 55,91 \\
\hline & 5,00 & 40 & 51,74 \\
\hline & 6,00 & 22 & 58,50 \\
\hline & 7,00 & 2 & 78,50 \\
\hline & Total & 106 & \\
\hline \multirow[t]{7}{*}{ Controle Acaso } & 2,00 & 5 & 52,70 \\
\hline & 3,00 & 4 & 53,50 \\
\hline & 4,00 & 33 & 59,24 \\
\hline & 5,00 & 40 & 55,05 \\
\hline & 6,00 & 22 & 43,73 \\
\hline & 7,00 & 2 & 37,25 \\
\hline & Total & 106 & \\
\hline \multirow[t]{7}{*}{ Flow } & 2,00 & 5 & 46,70 \\
\hline & 3,00 & 4 & 52,00 \\
\hline & 4,00 & 33 & 49,59 \\
\hline & 5,00 & 40 & 54,65 \\
\hline & 6,00 & 22 & 59,23 \\
\hline & 7,00 & 2 & 52,00 \\
\hline & Total & 106 & \\
\hline
\end{tabular}


Tabela 21 - Teste H de Kruskal-Wallis para as variáveis Controle Acaso, Flow, NSE, Idade e Sexo, com respeito à variável de Grupo Felicidade.

\begin{tabular}{|l|r|r|r|r|r|}
\hline & \multicolumn{1}{c|}{$\begin{array}{c}\text { Controle } \\
\text { Acaso }\end{array}$} & \multicolumn{1}{c|}{ Sexo } & Idade & $\begin{array}{c}\text { Nível Sócio } \\
\text { Econômico }\end{array}$ & \multicolumn{1}{c|}{ Flow } \\
\hline Chi-Square & 4,224 & 2,266 & 1,231 & 6,047 & 2,156 \\
\hline df & 5 & 5 & 5 & 5 & 5 \\
\hline Asymp. Sig. &, 518 &, 811 &, 942 &, 302 &, 827 \\
\hline
\end{tabular}

a Kruskal Wallis Test

b Variável de Grupo: Felicidade

Fonte: SPSS

Conforme podemos observar nas tabelas 20 e 21, o teste de Kruskall-Wallis indicou que as variáveis Flow, Sexo, Idade e Nível sócio-econômico não se mostraram discriminantes em relação à variável Felicidade $(H=2,156 ; p \leq 0,827) ;(H=2,266 ; p \leq$ 0,811); $(H=1,231 ; p \leq 0,942)$ e $(H=6,047 ; p \leq 0,302)$, respectivamente. Isso significa que as variações encontradas entre as populações não correspondem a diferenças efetivas entre elas, representando, isto sim, apenas variações aleatórias, passíveis de serem encontradas em quaisquer amostras aleatórias de uma mesma população. 


\section{V- DISCUSSÃO E CONCLUSÕES}

Nos últimos anos a Psicologia enquanto Ciência tem se mostrado bastante eficaz no tratamento das doenças mentais e alívio do sofrimento humano. Por outro lado, seu caráter preventivo não tem sido tão bem explorado quanto haveríamos de supor, sobretudo considerando-se a realidade econômica dos países pobres.

O Brasil, país conhecido por seus contrastes, tem sido referencial para países de primeiro mundo no tocante a iniciativas na área da saúde, tais como a subvenção governamental ao tratamento da AIDS, ou ainda a fabricação de medicamentos genéricos. No entanto, ainda estamos longe de conquistas básicas como a garantia de um atendimento em saúde de qualidade (em meio do qual o serviço psicológico aparenta ser um luxo) para a população de baixa renda.

Interessada no estudo dos aspectos funcionais do ser humano, a Psicologia Positiva não pretende substituir a visão de uma Psicologia focada no tratamento do sofrimento humano, mas sim ampliar essa visão a fim de que possamos criar um corpo teórico capaz de subsidiar iniciativas preventivas em relação a tal sofrimento. Este trabalho buscou exatamente explorar essa possibilidade, iniciando uma investigação acerca de características ou habilidades pessoais, mais especificamente locus de controle e flow, capazes de facilitar a felicidade humana.

Os resultados indicaram a confirmação da hipótese inicial da pesquisa, ou seja, a de que o bem-estar-subjetivo (ou felicidade) possui uma correlação positiva com o locus de controle interno.

Conforme pudemos observar na sessão de resultados, existe uma moderada correlação positiva entre as variáveis "Grau de felicidade" e "Controle interno" $(r=0,335 ; p \leq 0,01)$, ao mesmo tempo em que pudemos verificar uma moderada 
correlação negativa entre "Grau de Felicidade" e "Controle Externo" ( $r=0,326 ; p \leq$ 0,01). Além disso, a aplicação de um teste mais robusto e de caráter inferencial como o Kruskall-Wallis indicou, conforme vimos nas tabelas 18 e 19, os graus de Controle Interno e Externo como discriminantes em relação à variável Felicidade $(H=16,82 ; p \leq$ $0,005)$ e $(H=13,93 ; p \leq 0,016)$, respectivamente, porém em sentidos opostos. Em outras palavras, isso significa que, na amostra estudada, quanto maior a sensação de controlar sua própria vida (locus de controle interno) o indivíduo apresentou, maior também foram seus níveis de felicidade, enquanto que o controle externo manteve com a variável felicidade, enquanto que o controle externo manteve com a variável felicidade uma relação inversamente proporcional. Considerando o tamanho da amostra, não seríamos levianos ao afirmar que quanto maior o locus de controle interno do indivíduo, maiores suas chances de ser uma pessoa feliz. No entanto estamos cientes de que afirmações mais contundentes nesse sentido, careceriam de uma amostra mais diversificada. Ainda assim, não nos parece prudente subestimar a importância do locus interno nos níveis de felicidade de um indivíduo. Existe em nossa cultura a falsa idéia de que a pessoa feliz é aquela que nasceu predestinada ou como popularmente costuma ser dito, nasceu "virada para a Lua". Essa maneira de pensar que atrela a felicidade à sorte ou acaso, além de ter sido descartada por nossa pesquisa $(H=4,224 p \leq 0,518)$, conforme mostram as tabelas 20 e 21 , subestima 0 papel do indivíduo na construção de sua própria felicidade. Por outro lado, a hipótese comprovada nos parece bastante compreensível uma vez que é lógico supormos que, em geral, o indivíduo que acredita controlar sua vida, também acredita na felicidade como resultado de seu esforço, dedicando-se, assim, muito mais à sua conquista. 
É possível que a crença no locus de controle interno seja favorecida pela cultura ocidental contemporânea que valoriza o indivíduo e as liberdades individuais; daí, inclusive, um maior bem-estar que esse indivíduo pode experimentar por estar em sintonia com a cultura a qual pertence.

Contudo, isso não significa que ao falarmos de controle interno estejamos falando de individualismo. Nesse sentido devemos lembrar que, como visto no capítulo 1.2.1., um sujeito individualista é alguém cujo self embora diferenciado, não fora integrado, ou seja, unido com outras pessoas, idéias e seres exteriores a ele (Csikszentmihalyi, 1992). Considerando que a complexidade (diferenciação e integração) do self é uma peça-chave para uma vida feliz (Seligman, 2004) definitivamente não poderíamos tomar os sujeitos com locus interno por pessoas individualistas.

Um outro aspecto que deve ser salientado é o de que, ao afirmarmos que quanto maior o controle interno, maior o nível de felicidade, estamos excluindo os casos de um controle interno neurótico, que ignora as limitações do indivíduo frente ao controle de sua vida, assim como a influência do acaso e dos outros sobre si próprio. Além disso é fundamental observamos que o instrumento que utilizamos para a mensuração do lócus de controle não foi desenvolvido para a avaliação do que aqui estamos chamando de controle neurótico, ou ainda de um controle interno disfuncional. Não há nada que indique que um sujeito com locus de controle interno nível 8 ignore suas limitações pessoais e acredite ser o único com poder para controlar sua própria vida. 
Quanto à hipótese secundária desta pesquisa, não pudemos confirmá-la muito provavelmente em função das limitações do instrumento desenvolvido para a avaliação do flow, as quais já foram discutidas no item 4.1. De qualquer forma, vale dizer que no teste de Kruskall-Wallis as variáveis Flow, Sexo, Idade e Nível sócioeconômico não se mostraram discriminantes em relação à variável Felicidade $(H=$ 2,156; $p \leq 0,827) ;(H=2,266 ; p \leq 0,811) ;(H=1,231 ; p \leq 0,942)$ e $(H=6,047 ; p \leq$ 0,302), conforme já vimos nas tabelas 21 e 22. Exceção feita ao Flow, os resultados encontrados coincidem com a literatura. De acordo com Seligman (2004) os níveis de felicidade não variam em função de gênero ou da idade do indivíduo, embora esta última modifique ligeiramente a intensidade das emoções. Com relação ao nível sócioeconômico, nosso estudo corrobora a literatura que diz que, mantidas as condições básicas de sobrevivência, o dinheiro não se relaciona com felicidade (Csikszentmihalyi, 1999).

De uma forma geral, os resultados apresentados sugerem ser esta uma linha de pesquisa promissora, que deixa margem à elaboração de futuras questões tais como: a-) Existem outras características ou habilidades humanas capazes de favorecer a felicidade? b-) Em caso positivo, até que ponto seria possível a criação de programas voltados para o desenvolvimento de tais características e habilidades?

c-) Uma vez que o flow esteja correlacionado à felicidade e que sua ocorrência de fato dependa da metacognição, um treino metacognitivo poderia, por extensão, aumentar as chances de o sujeito ter uma vida mais feliz?

d-) Com uma amostra mais diversificada, chegaríamos aos mesmos resultados? 
e-) Na medida em que concebemos a Felicidade como uma variável latente, quais outras variáveis a compõem?

Em resumo, podemos dizer que os resultados deste trabalho muito antes de elucidar os caminhos que levam à felicidade humana, possibilitaram apenas a compreensão de alguns de seus aspectos. É fundamental, no entanto que continuemos a estudar e, sobretudo, que a Psicologia não tenha pudores em (re)assumir este tema como objeto de estudo. 


\section{REFERÊNCIAS BIBLIOGRÁFICAS}

Antunes, M.A.M. (2003). A psicologia no Brasil: São Paulo: Unimarco Editora / EDUC. Leitura histórica sobre sua constituição.

Appolinario, F. (2004). Dicionário de metodologia científica: Um guia para a produção do conhecimento científico. São Paulo: Atlas.

Aristóteles (1987). Ética a Nicômaco. Coleção os Pensadores. São Paulo: Nova Cultural.

Associação Nacional de Empresas de Pesquisa (1996) Critério Brasil de classificação econômica. São Paulo: ANEP. Disponível na Internet: em iwwW.anep.org. bir [01 agosto 2004].

Bandura (1977). Self-efficacy: Toward a unifying theory of behavioral change. Psychological Review, 84, 191- 215.

Bradburn, N. (1969). The structure of a psychological well-being. Chicago: Aldine.

Brickman, P., Coates, D. \& Bulman, J. (1978). Lottery winners and accident victims: Is happiness relative? Journal of Personality and Social Psychology, vol. $36 n^{\circ} 8$, $917-927$.

Bryant, F. (1989). A four-factor model of perceived control: Avoiding, coping, obtaining and savoring. Journal of Personality, 57, 773-797.

Corsini, R. (2002). The dictionary of Psychology. New York: Brunner-Routledge.

Csikszentmihalyi, M. (1992). A Psicologia da Felicidade. São Paulo: Saraiva.

Csikszentmihalyi, M. (1999). If we are so rich, why aren't we happy?. American Psychologist, 54, $821-835$. 
De Masi, D. (1999). O futuro do trabalho: Fadiga e ócio na sociedade contemporânea. Rio de Janeiro: José Olympio; DF: Editora UnB.

Della Coleta (1979). A escala de locus de controle interno-externo de Rotter: Um estudo exploratório. Arquivos Brasileiros de Psicologia, 31 (4), 167 - 181.

Delumeau, J. (1997). Mil anos de felicidade: Uma história do paraíso. São Paulo: Companhia das Letras.

Dennett, D. (1991). Consciousness explained. Boston: Little Brown.

Diener, E. \& Larsen, R. (1984). Temporal stability and cross-situational consistency of affective, behavioral and cognitive responses. Journal of Personality and Social Psychology. 47, 871 - 883.

Diener, E. (1984). Subjective well-being. Psychological Bulletin, $95 n^{\circ} 3,542-575$.

Diener, E. (1999). Subjective well-being: Three decades of progress. Psychological Bulletin, 125 n², 276 - 302.

Diener, E. (2000). Subjetive well-being: The science of happiness and a proposal for a national index. . American Psychologist, 55, 34 - 43.

Diener, Lucas \& Oishi (2002). Subjetive well-being: The science of happiness and life satisfaction. In: SNYDER, C. R. \& LOPEZ, S. orgs. Handbook of Positive Psychology. New York, Oxford,p. 63- 73.

Epicuro (1994). Carta sobre a felicidade. Tradução de João Forte. Lisboa: Relógio D’Água Editores. 
Fllugel, J. (1925). A quantitative study of feeling and emotion in every-day life. British Journal of Psychology, 9, 318 - 355.

Fournier, G. \& Jeanrie, C. (2003). Locus of control: Back to Basis. In: Lopez, S. \& Snyder, C.R. orgs. Positive Psychological Assessment. New York, American Psychological Association.

Fredrickson, B. L.(2001). The role of positive emotions in positive psychology: The broaden-and-built theory of positive emotions. American Psychologist, 55, 218 - 226.

Freud, S. (1998 [1920]). Além do princípio do prazer. Trad.: Christiano Monteiro Oiticica. Rio de Janeiro, Imago.

Graziano, L. (1998). Vítor e sua vitória: A construção da identidade de um militante através da AIDS. Dissertação de Mestrado. Universidade São Marcos, São Paulo.

Gurin, Gurin \& Morrison (1978). Personal and ideological aspects of internal and external control. Social Psychology, 41 (4) 275 - 296.

Hewitt, J. (2002). The Social construction of self-esteem. In: Snyder, C. R. \& Lopez, S. orgs. Handbook of Positive Psychology. New York, Oxford,p.135 - 148

Johnson-Laird, P. (1983). Mental models. Cambridge, Mass.:Harvard University Press.

Kraut,R. et all (1998). Internet Paradox: A Social Technology that reduces social involvement and psychological well-being? American Psychologist, 53, 1017 - 1031 
Larson, R.W. (2000) Toward a psychology of positive youth Development. American Psychologist, 55, 170-183.

La Taille, Yves de (2002). Vergonha: A ferida moral. Petrópolis, R.J.: Vozes.

Lefcourt, H. (1976). Locus of Control: Current trends in theory and research. New Jersey: Lawrence Erlbaum.

Levenson, $H$ (1974). Activism and powerful others: distinctions within the concept of internal-external control. Journal of Personality Assessment, 38, 377-383.

Lyubomirsky, S. (2001). Why are some people happier than others: The role of cognitive and motivacional processes in well-being. American Psychologist, 56, 239 -249 .

Lyubomirsky, S. \& Lepper, H. (1999). A measure of subjective happiness: preliminary reliability and construct validation. Social Indicators Research, 46, 137 - 155.

Locke, E. (2002). Setting goals for life and happiness. In: Snyder, C. R. \& Lopez, S. orgs. Handbook of positive psychology. New York, Oxford, p.299 -312.

Maddux, J. (2002). Stopping the "madness": Positive Psychology and deconstruction of the illness ideology and DSM. In: SNYDER, C. R. \& LOPEZ, S. orgs. Handbook of positive psychology. New York, Oxford, p.13-25.

Mahoney, M. (1998). Processos humanos de mudança: As bases científicas da psicoterapia. Porto Alegre, Artmed.

Marías,J. (1989). A felicidade humana. São Paulo: Duas Cidades. 
Marsella, A.J. (1998). Toward a "global-community psychology": Meeting the needs of a changing world. American Psychologist, 53, 1282 - 1291.

Massimini, F. \& Delle Fave, A. (2000). Individual Development in a bio-cultural perspective. American Psychologist, 55, 24 a 33.

Maturana, H. ( 2001) Cognição, ciência e vida cotidiana. Belo Horizonte: Editora UFMG.

Maturana, H. (2002). Emoções e linguagem na educação e na política. Belo Horizonte: Editora UFMG.

Ministério da Saúde (1997). Resolução CNS 196/96: Diretrizes e normas regulamentadoras de pesquisas envolvendo seres humanos. Brasília: Conselho Nacional de Ética em Pesquisa, Ministério da Saúde. Disponível na Internet:

hittp://conselho.saude.gov.br/comissao/eticapesg 2.htm \#resolucoès, [31 julho 2004].

Moneta, G. \& Csikszentmihalyi, M. (1996). The effect of perceived challenges and skills on the quality of subjective experience. Journal of Personality, 64, $275-310$.

Nakamura, J. \& Csikszentmihalyi, M.(2002). The concept of flow. In: Snyder, C. R. \& Lopez, S. orgs. Handbook of positive psychology. New York, Oxford, p.89-106

Paulhus, D. L. (1983). Sphere - specific measures of perceived control. Journal of Personality and Social Psychology, 44 (6) 1253 - 1265.

Peterson, C. \& Seligman, M. (2004). Character strengths and virtues: A handbook and classification. New York: American Psychological Association, Oxford University Press. 
Phares, E. (1976). Locus of control in personality. Morristown, N.J.: General Learning Press.

Pinker, S. (1998). Como a mente funciona. São Paulo: Companhia das Letras.

Pinker, S. (2004). Tabula Rasa: A negação contemporânea da natureza humana. São Paulo: Companhia das Letras.

Reivich, K. \& Shatté, A. (2002). The resilience factor: 7 essential skills for overcoming life's inevitable obstacles. New York: Broadway Books.

Rotter, J. (1966). Generalized expectancies for internal versus external control of reinforcement, Psychological Monographs, 80, 609.

Rotter, J. (1975). Some problems and misconceptions related to the construct of internal versus external control of reinforcement. Journal of Consulting and Clinical Psychology, 48, 56 - 67.

Russel, B. (2003). A conquista da felicidade. Tradução: Luis Guerra. Rio de Janeiro: Ediouro.

Sandvik, E. ; Diener, E. \& Seidlitz, L. (1993). Subjetive well-being: The convergence and stability of self-report and non-self-report measures. Journal of Personality, 61, $317-342$.

Seligman, M.(1994). What you can change and what you can't. New York: Knopf.

Seligman, M. (2004). Felicidade Autêntica: Usando a nova Psicologia Positiva para a realização permanente. Rio de Janeiro: Objetiva. 
Seligman, M. \& Csikszentmihalyi, M. (2000). Positive Psychology: An introduction. American Psychologist, 55, 5-14.

Sêneca (1994). Da vida feliz. Tradução João Forte. Lisboa: Relógio D’Água Editores.

Sheldon, K.M. \& King, L. (2001) Why positive psychology is necessary. American Psychologist, 56, 216-217.

Siegel, S. (1979). Estatística Não-paramétrica para as ciências do comportamento. Rio de Janeiro: McGraw-Hill.

Snyder, C., Rand, K. \& Sigmon, D. (2002). Hope theory: The power of the positive psychology family. In: Snyder, C. R. \& Lopez, S. orgs. Handbook of positive psychology. New York, Oxford, 2002. p.275 - 266.

SPSS (2003). Base 12.0 user's guide. Chicago: SPSS.

Tellegen, A. et all. (1998) Personality similarity in twins reared apart and together. Journal of Personality and Social Psychology. 54, 1031 - 1039.

Thagard, P. (1998). Mente: Uma introdução à ciência cognitiva. Porto Alegre, ArtMed.

Thompson, S. (2002). The role of personal control in adaptive functioning. In: Snyder, C. R. \& Lopez, S. orgs. Handbook of positive psychology. New York, Oxford, 2002. p $202-214$.

Vygotsky, L. (1978) Mind in society: The development of higher psychological processes. Cambridge, Harvard University Press.

Wright, R. (2000). Não Zero: A lógica do destino humano. Rio de Janeiro: Campus. 


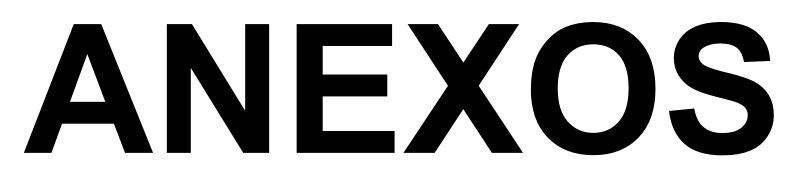




\section{Anexo I - Critério de Classificação Econômica Brasil}

Assinale a coluna correspondente à quantidade existente em sua casa, de cada um dos seguintes itens:

Posse de Itens

\begin{tabular}{|l|l|l|l|l|l|}
\hline & NÃO & \multicolumn{5}{c|}{ TEM } \\
\cline { 4 - 7 } & TEM & $\mathbf{1}$ & $\mathbf{2}$ & $\mathbf{3}$ & $\mathbf{4}$ ou + \\
\hline \hline \multicolumn{1}{|c|}{ Televisão em cores } & & & & & \\
\hline Rádio (exceto do carro) & & & & & \\
\hline Banheiro & & & & & \\
\hline Automóvel * & & & & & \\
\hline Empregada Mensalista & & & & & \\
\hline Aspirador de pó & & & & & \\
\hline Máquina de lavar roupa & & & & & \\
\hline Vídeo cassete e/ou DVD & & & & & \\
\hline Geladeira & & & & & \\
\hline $\begin{array}{l}\text { Freezer (aparelho independente } \\
\text { ou parte de geladeira duplex) }\end{array}$ & & & & & \\
\hline
\end{tabular}

* Não considerar táxis, vans ou pick-ups usados para fretes, ou qualquer veículo de propriedade de empresa ou usado para atividades profissionais.

Assinale o Grau de Instrução do chefe da família:

Analfabeto / Primário Incompleto

Primário Completo / Ginasial Incompleto

Ginasial Completo / Colegial Incompleto

Colegial Completo / Superior Incompleto

Superior Completo 


\section{Anexo II - Escala Geral de Felicidade de Lyubomirsky \& Lepper}

Para cada uma das seguintes afirmações e/ou perguntas, circule o número de pontos da escala que considerar mais apropriado a você.

1- Em geral, considero-me:

\begin{tabular}{|c|c|c|c|c|c|c|}
\hline 1 & 2 & 3 & 4 & 5 & 6 & 7 \\
\hline $\begin{array}{l}\text { Uma pessoa } \\
\text { não muito } \\
\text { feliz }\end{array}$ & & & & & & $\begin{array}{c}\text { Uma pessoa } \\
\text { muito } \\
\text { feliz }\end{array}$ \\
\hline
\end{tabular}

2- Comparando com a maioria dos meus amigos, eu me considero:

$\begin{array}{ccccccc}\begin{array}{c}\text { Menos } \\ \text { feliz }\end{array} & 2 & 3 & 4 & 5 & 6 & \begin{array}{c}7 \\ \text { Mais } \\ \text { feliz }\end{array}\end{array}$

3- Algumas pessoas são, geralmente, muito felizes. Elas aproveitam a vida, aconteça o que acontecer, procurando obter o máximo. Em que grau essa descrição se aplica a você?

$\begin{array}{ccccccc}1 & 2 & 3 & 4 & 5 & 6 & 7 \\ \begin{array}{c}\text { De modo } \\ \text { algum }\end{array} & & & & & & \text { Muito }\end{array}$

4- Algumas pessoas, geralmente, não são muito felizes. Embora não estejam deprimidas, nunca parecem tão felizes quanto poderiam ser. Em que grau essa descrição se aplica a você?

$\begin{array}{cccccccc}1 & 2 & 3 & 4 & 5 & 6 & \begin{array}{c}7 \\ \text { De modo } \\ \text { algum }\end{array}\end{array}$




\section{Anexo III - Escala Multidimensional de Locus de Controle de Levenson}

Para cada afirmação abaixo, responda CONCORDO $(\mathrm{C})$ quando a mesma coincidir com o que você pensa e DISCORDO (D) quando a frase não exprimir a sua opinião.

1- Se eu vou ou não tornar-me um líder, depende principalmente de minha capacidade. ( )

2- Minha vida é, em grande parte, determinada por acontecimentos inesperados. ( )

3- Sinto que o que ocorre em minha vida é determinado principalmente por pessoas mais poderosas que eu. ( )

4- Se eu vou ou não sofrer um acidente de automóvel, depende, principalmente, de eu ser ou não cuidadoso(a). ( ).

5- Quando faço planos, sempre tenho certeza de que vou realizá-los. ( )

5- Geralmente não tenho oportunidade de proteger meus interesses pessoais da influência do azar. ( )

7- Quando eu consigo o que quero, freqüentemente é porque tenho sorte. ( )

8- Embora eu tenha muita capacidade, só conseguirei ter uma posição importante se pedir ajuda a pessoas de prestígio. ( )

9- A quantidade de amigos que tenho depende de quão agradável eu sou. ( )

10- Verifico, freqüentemente, que o que está para acontecer, acontecerá. ( )

11- Minha vida é controlada principalmente por pessoas poderosas. ( )

12- Se eu vou ou não sofrer um acidente de automóvel, isto é principalmente uma questão de sorte. ( )

13- As pessoas como eu têm poucas chances de proteger seus interesses pessoais. ( )

14- Nem sempre é desejável para mim fazer planos com muita antecedência, porque muitas coisas acontecem por uma questão de má ou boa sorte. ( )

15-Para conseguir o que desejo preciso da ajuda de pessoas superiores a $\operatorname{mim} .($ )

16- Se eu vou ou não tornar-me um líder, depende principalmente de eu ter sorte o suficiente para estar no lugar certo, na hora certa. ( )

17- Se as pessoas importantes decidirem que não gostam de mim, provavelmente eu não conseguirei ter muitos amigos. ( )

18- Eu posso, quase sempre, determinar o que vai acontecer na minha vida. ( )

19- Freqüentemente eu sou capaz de proteger meus interesses pessoais. ( ) 
20- Se eu vou ou não sofrer um acidente de automóvel, depende muito do outro motorista. ( )

21- Quando eu consigo o que quero, freqüentemente é porque me esforcei muito. ( )

22- Para que meus planos se realizem, devo fazer com que eles se ajustem aos desejos das pessoas mais poderosas do que eu. ( )

23- Minha vida é determinada por minhas próprias ações. ( )

24- $O$ fato de eu ter poucos ou muitos amigos deve-se, principalmente, à influência do destino. ( ) 


\section{Anexo IV - Modelo de Questionário de Flow}

Este questionário visa identificar o que chamamos de atividade autotélica, ou seja um tipo de atividade que você considere recompensadora por si mesma, independente do resultado que ela possa lhe trazer. Por exemplo, uma pessoa que considere a leitura de um livro como sendo uma atividade autotélica, vê a própria leitura como sendo altamente recompensadora, de forma que ela lê por gostar da leitura em si e não porque, lendo o livro, poderá se sair melhor numa prova. Porém, nem todas as pessoas experimentam esse tipo de atividade, de forma que você não deve se preocupar se este for o seu caso. Apenas procure se lembrar se existe alguma atividade em sua vida que se encaixe nessa definição e responda atentamente as questões abaixo:

\section{Questionário}

1-) Atualmente existe algum tipo de atividade que você considere recompensadora por si mesma e na qual você consiga se concentrar totalmente, a ponto de ser capaz de perder a noção do tempo?

( ) Sim ( ) Não

Em caso positivo, continue respondendo as questões abaixo:

2-) Explique que tipo de atividade é essa e como você a executa.

3-) Aproximadamente com que freqüência você costuma praticar essa atividade?

( ) Acima de 2 vezes por semana

( ) De uma a duas vezes por semana

( ) Duas vezes por mês

( ) Uma vez por mês

( ) Raramente

4-) Uma vez que esteja se dedicando a essa atividade, com que freqüência consegue obter concentração total no que está fazendo?

( ) Sempre

( ) A maioria das vezes

( ) Apenas em algumas das vezes

( ) Raramente

5-) O que você mais gosta nessa atividade?

6-)Você sente que essa atividade lhe exige exatamente o que você tem de melhor a oferecer? ( ) Sim ( ) Não ( ) Não sei.

7-) Caso tenha respondido afirmativamente a questão anterior, você diria que o grau dessa exigência, numa escala de 1 a 5 , seria:

$\begin{array}{ccccc}1 & 2 & 3 & 4 & 5 \\ \begin{array}{c}\text { Exigência } \\ \text { Muito Baixa }\end{array} & & & & \text { Exigência } \\ \text { Muito Alta }\end{array}$




\section{Anexo V - Consentimento Informado}

\section{A) Identificação e Proposta}

A profa. Lílian D. Graziano CRP 06/48.425-7, está conduzindo um estudo que será objeto de sua tese de Doutorado, sobre o tema Felicidade. Nesse sentido, solicita sua participação como sujeito dessa pesquisa.

\section{B) Convite e Recusa}

$\mathrm{Eu}$, estou sendo convidado a participar desta pesquisa, tendo sido selecionado em função de atender aos pré-requisitos definidos. Eu sei que a minha participação nesta pesquisa é absolutamente voluntária. Eu tenho o direito de recusar a participar ou desistir em qualquer ponto deste estudo. Minha decisão em participar ou não desta pesquisa não terá nenhum tipo de conseqüência pessoal ou institucional.

\section{C) Procedimentos}

Se eu concordar em participar deste estudo, o seguinte ocorrerá: Serei submetido à uma bateria de testes psicológicos que visam dimensionar aspectos tais como bem-estar e determinadas habilidades cognitivas. A aplicação destes testes se dará numa sala ampla onde haverá outras pessoas que também serão submetidas a tais testes, porém que não terão acesso às minhas respostas.

Após esta bateria de testes, é possível que haja a necessidade de eu dê uma entrevista individual complementar.

\section{D) Risco / Desconforto}

Não há nenhum efeito prejudicial antecipado em participar desta pesquisa . Algumas das perguntas do questionário podem ser consideradas pessoais (p. ex., nível de escolaridade do chefe da família). Se algumas dessas perguntas, contudo, me deixarem chateado ou desconfortável, eu sou livre para me recusar a responder às perguntas, fazer os testes ou abandonar a sala onde a testagem será realizada.

\section{E) Sigilo}

Meus dados serão guardados e utilizados o mais confidencialmente possível. Nenhuma identidade pessoal será usada em qualquer relato ou publicação que possam resultar desse estudo. Nenhum nome será associado ao questionário ou aos testes psicológicos. Tais documentos serão numerados e somente o pesquisador terá acesso às informações que poderiam associar o número à pessoa. Estas informações ficarão trancadas em um lugar diferente dos questionários. 


\section{F) Questões}

Se eu tiver alguma questão ou comentário sobre a minha participação neste projeto, poderei conversar com o Profa. Dra. Maria Isabel da Silva Leme (Instituto de Psicologia da USP) ou diretamente com a profa. Lílian Graziano, responsável pela pesquisa.

\section{G) Consentimento}

Após a leitura deste documento, tive a oportunidade de esclarecer minhas eventuais dúvidas, de forma que declaro ter compreendido tudo o que li.

Data: 
This document was created with Win2PDF available at http://www.win2pdf.com.

The unregistered version of Win2PDF is for evaluation or non-commercial use only. 